\title{
PHENOMENA AFFECTING IMPROVEMENT OF THE LOWER COLUMBIA ESTUARY AND ENTRANCE
}

\author{
John B. Lockett \\ Chief, Special Projects Investigation Section \\ U. S. Army Englneer Division, North Pacific \\ Portland, Oregon
}

This paper describes work undertaken to improve the lower Columbia Estuary and Entrance for navigation and discusses past concepts of phenomena controlling the regimen of this area as related to these 1mprovements. Recent advances in technology have given birth to a new concept of tidal hydraulic phenomena which emphasizes the relation of salinity intrusion and littoral movement to the degree of shoaling experienced in estuarine areas. The findings of prototype measurements undertaken in 1959 along the lower Columbia, and other endeavors to expand the knowledge of controlling phenomena, including statistical wave studies, analyses of offshore changes, studies of attrition and accretion of adjacent shorelines, and comprehensive investigations of the distribution of Columbia River sediments are reviewed in the light of this new concept. Authorization, construction and verification of the comprehensive lower Columbia Estuary hydraulic model are discussed, as well as tests proposed for identification of controlling phenomena and for development of the most effective and economical plan of lmprovenent. Finally, the paper sumnarizes the extent of present knowledge and outlines considerations for the future under conditions of controlled upland discharge resulting from contemplated headwater reservoir operation.

\section{INTRODUCTION}

\section{THE RIVER}

Physical Characteristics - Columbla River rises in Columbia Lake, British Columbia, Canada, and flows in a circuitous course for 452 miles to cross the International Boundary, from where it flows generally southward 435 miles across the state of Washington to the Washington-Oregon state line, thence generally westward for 310 miles through the Cascade and Coast Ranges to empty into the Pacific Ocean near Astoria, Oregon, as shown on Figure 1. The river and its tributaries drain an area of 259,000 square miles, consisting 


\section{COASTAL ENGINEERING}

of rugged mountain ranges separated by valley troughs, trenches, and plateaus, of which 39,500 square miles lie in Canada. Elevations in the basin range up to nearly 14,000 feet above sea level in the Rocky Mountain system on the east. The total fall of the Columbia River from its source to the Pacific Ocean is 2,652 feet.

Run-off - The normal annual run-off of the Columbia River is 180,100,000 acre-feet and the discharge pattern of the lower river is quite regular with low flows occurring from September through March and high flows from April through August. At The Dalles, Oregon, 192 miles above the entrance, the mean annual run-off is 133,700,000 acre-feet and extremes in mean daily discharge at this point have ranged from 36,000 cfs to $1,240,000$ cfs.

Role in Economic Development - Water resource development has been of basic significance in the economic evolution of the Pacific Northwest which has in recent years emerged from an almost complete dependency on its basic resources of agriculture and timber to diversification and broadening of economic activities by production of more and more finished products. Water transportation by inland rivers, the Pacific Ocean, and the Puget Sound area has played a major role in the economic expansion of this great region. With suitable harbors that are strategically located, a flourishing trade has developed with Alaska, Canada, the Far East, California and the East Coast of the United States. The Columbia River, the most important inland waterway, provides a route for ocean-going traffic from its mouth to Vancouver, Washington. and, through the connecting willamette River, to Portland, oregon. Improvements are being undertaken to extend deepwater navigation with authorized channel depth of 27 feet to The Dalles. Barge traffic extends up the Columbia to Pasco, Washington, by a combination of open-river regulation and slackwater navigation provided by Bonneville, The Dalles, John Day, and McNary Dams. With completion of four authorized dams on the Lower Snake River, slackwater navigation for barge traffic will then extend to Lewiston, Idaho. Progressive improvement of the Columbia River has been accompanied by significant increases in ocean-going commerce as shown by traffic trends of major comnodity groups in the following tabulation: 


\begin{tabular}{lrrrrr}
\hline & \multicolumn{5}{c}{ OCEAN-BORNE COMMERCE } \\
& \multicolumn{7}{c}{ (Thousands of Tons) } \\
\cline { 2 - 7 } & 1925 & 1940 & \multicolumn{1}{c}{1950} & 1955 & 1960 \\
\hline & 733 & 812 & 695 & 1,153 & 4,417 \\
Agricultural Products & 41 & 49 & 61 & 20 & 69 \\
Animal Products & 31 & 86 & 323 & 71 & 989 \\
Minerals & 1,998 & 1,962 & 1,372 & 1,775 & 1,041 \\
Forest Products & 1,720 & 3,050 & 5,971 & 7,090 & 5,551 \\
Petroleum Products & 713 & 965 & 792 & 820 & 426 \\
Miscellaneous & & & & & \\
\multicolumn{1}{c}{ Total } & 5,236 & 6,924 & 9,214 & 10,929 & 12,493 \\
\hline
\end{tabular}

\section{THE LOWER ESTUARY}

Extent - The Columbia Estuary proper, as affected by tidal variations, extends during periods of low river flows up to Bonneville Dam, on the Columbia River, 140 miles above the entrance, and to Willamette Falls at oregon City, on the Willamette River. At higher river stages the sections of the river thus affected by tidal conditions progressively move downstream. The reach below Oak Point, Washington (River Mile 52), shown on Figure 2, forms the lower Columbia Estuary and tidal conditions in this section generally have more effect on stages than river flows. In this reach the main river channel traverses a meandering course between generally widening bank lines, past many low islands and shoals to eventually join the Pacific Ocean between the rugged headlands of Cape Disappointment on the north and the lowlying Point Adams on the south.

Tidal Influence - Normally reversals of current direction occur throughout the lower Columbia Estuary as the result of tidal fluctuations of the Pacific Ocean. At Fort Stevens, River Mile 8 , the average daily tidal variation is about 8 feet. The lowest tide observed at this point was estimated to be 3.0 feet below mean lower low water and the highest stage, which resulted from a combination of storm activity and tidal action, was 11.6 feet above mean lower low water. The tidal prism of the Columbia Estuary has been estimated at 732 square-mile feet. 
PHENOMENA AFFECTING IMPROVEMENT OF THE LOWER COLUMBIA ESTUARY AND ENTRANCE
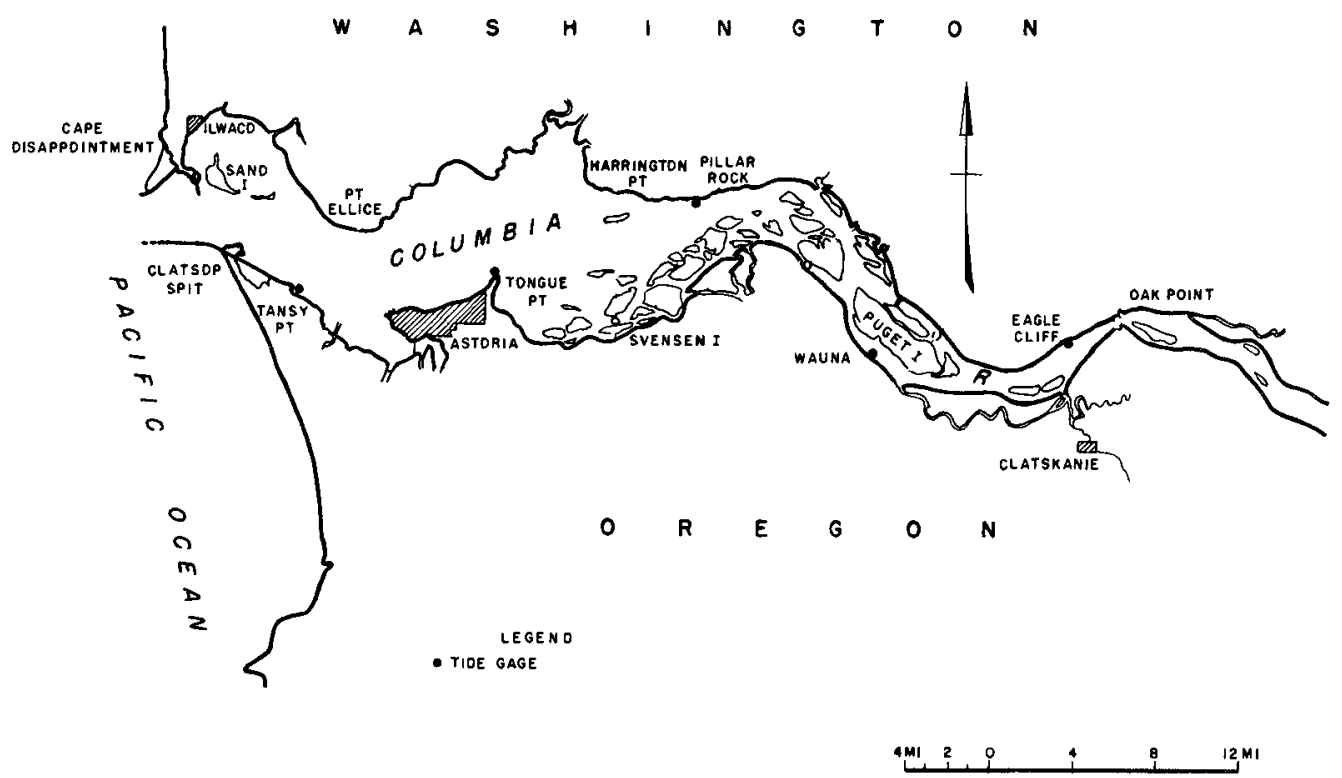

Fig. 2. Lower Columbia estuary.

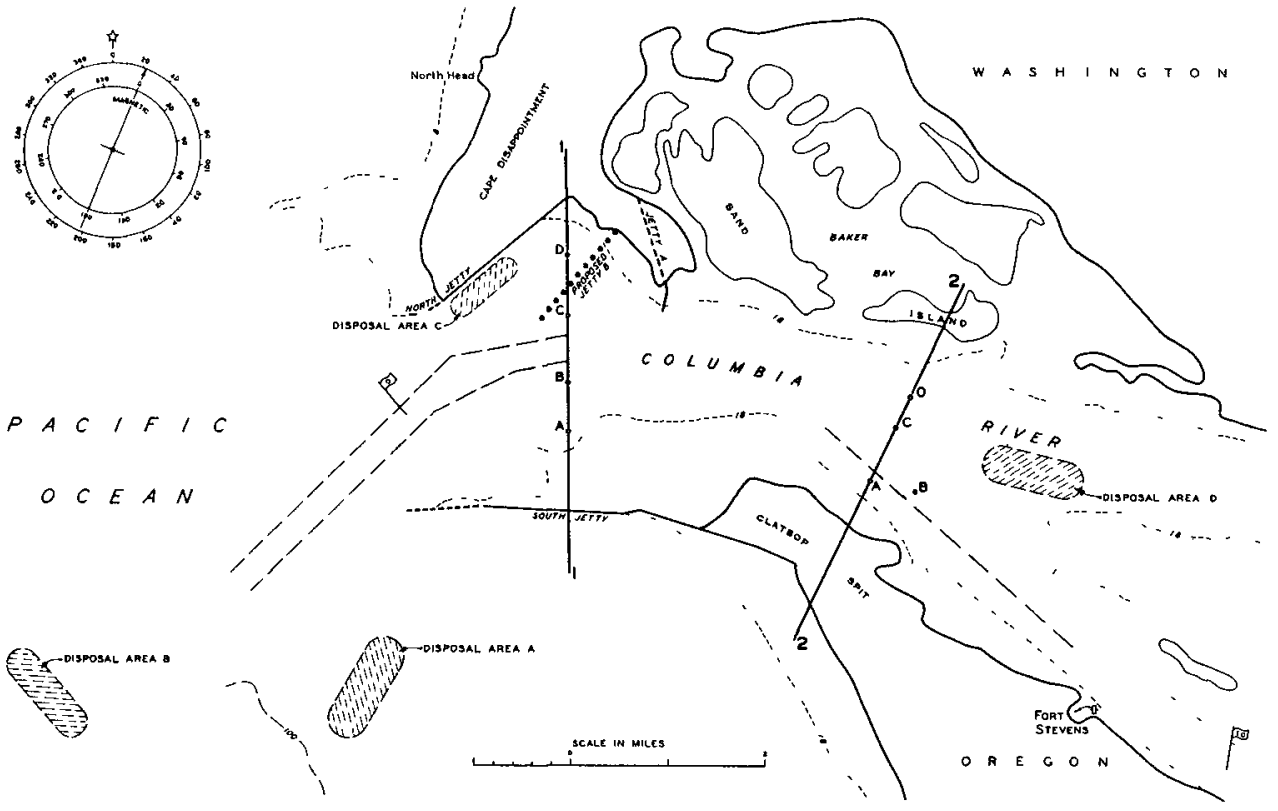

Fig. 3. Columbia entrance. 


\section{COASTAL ENGINEERING}

\section{THE ENTRANCE}

General - Perhaps the most consistent characteristic of the Columbia Entrance, Figure 3, is its continually changing regimen which strives to sreate a balance between the forces of the ocean and those of the river. This balance is quite delicate as any modification of the river forces in the entrance area, no matter how minor, is accompanied by a corresponding change in ocean forces and, as a consequence, throughout the period of man's endeavor to improve conditions for navigation the entrance has undergone many changes and has assumed many different complexions.

Tides - Tides at the Columbla River Entrance have the diurnal inequality typical of the Pacific Coast with a long run-out from higher high to lower low water. The mean range is 6.5 feet, the range from mean lower low water to mean higher high water is 8.5 feet, and extreme tides range from minus 2.6 feet to plus 11.6 feet, mean lower low water.

Winds and storms - Two seasons having wide variance in wind and sea conditions generally occur each year at the entrance. The season of severe storms usually extends from october to April and storm winds, beginning generally in the south quadrant, gradually veer to the southwest and finally blow thenselves out as they move around to the west or northwest. Storms are often continuous for several days and are accompanied by extrenely heavy seas mostly from the southwest During the sumner season, the conditions of wind and sea are much less severe than those of the winter season. From May through september, winds from the north or northeast begin in the morning, Increase in force during the day, and diminish at night. Occasionally during the winter and spring there are several days when an easterly wind predominates and the weather is cold.

\section{HISTORY}

\section{PRIOR TO IMPROVEMENT}

A chart, Figure 4, made under direction of Admiral vancouver clearly indicated the existence in 1792 of a single channel at the columbia entrance with a depth of 4-1/2 fathoms between Cape Disappointment and Point Adams. In $1839 \mathrm{sir}$ Edward Belcher revealed the existence of two channels at the entrance separated by a large shoal area which forced the deeper channel northward against Cape 
PHENOMENA AFFECTING IMPROVEMENT OF THE LOWER COLUMBIA ESTUARY AND ENTRANCE

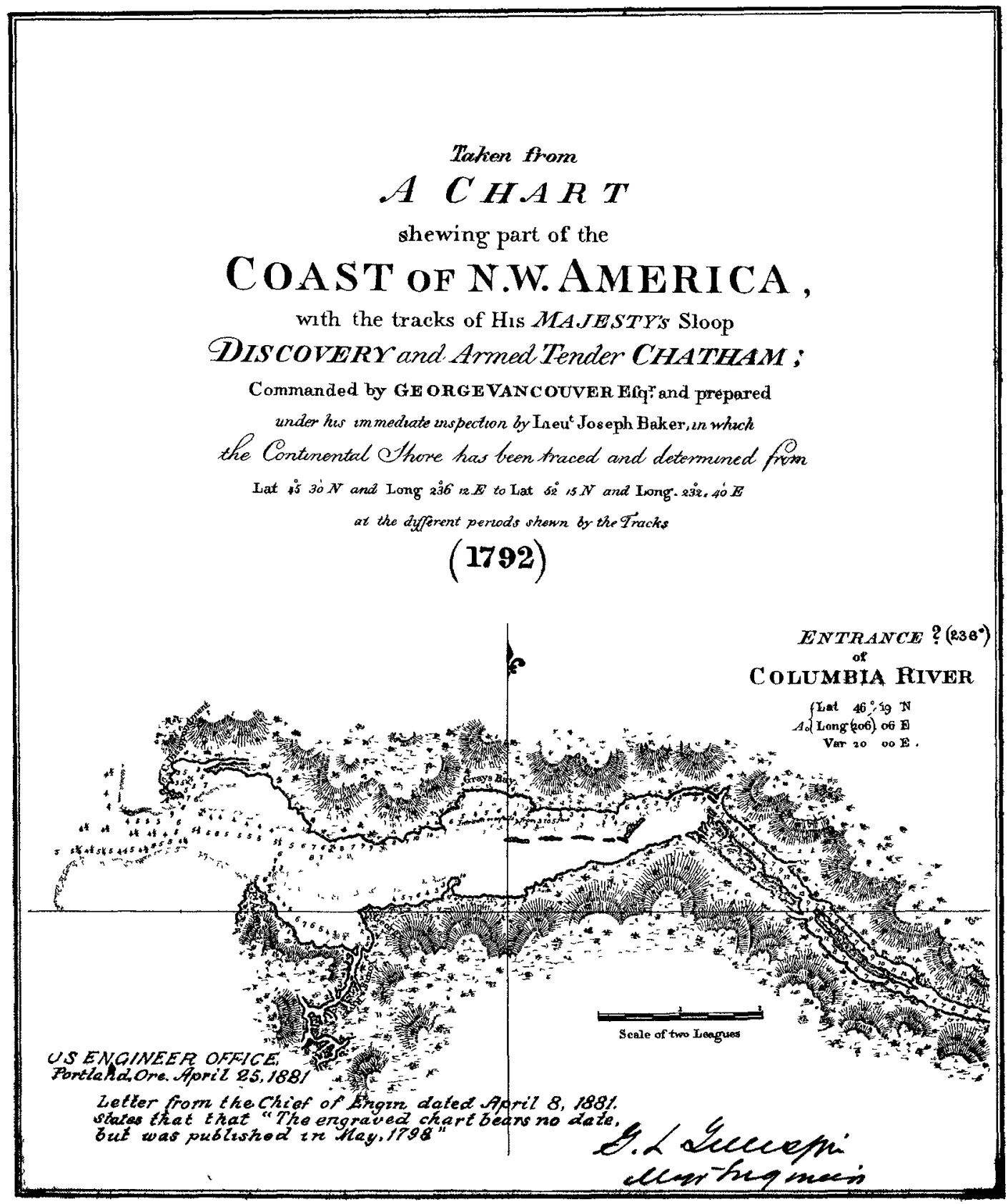

FIGURE 4. CHART BY ADMIRAL VANCOUVER 


\section{COASTAL ENGINEERING}

Disappointment to turn sharply southward and join a generally shallower channel along point Adams, as shown in Figure 5. This shoal area, called the Middle sands, grew in size until its 18-foot contour in 1874 embraced a very large area seaward and south of Cape Disappointment and covered almost all of the area now occupied by the present entrance. A portion of the Middle sands formed an island inside the entrance which later separated from the main shoal area and, migrating to the north to form sand Island, restored a single channel to the entrance in 1885. At that time the main portion of the Midale sands had moved westward to create a westward extension of Cape Disappointment and minimum depths of 20 feet prevailed on the ocean bar as shown in Figure 6 .

\section{0-FOOT ENTRANCE PROJECT}

Early attempts to improve the entrance, prior to the adoption by Congress in 1832 of the initial permanent navigation project, consisted of sporadic dredging in combination with the construction of temporary training structures. It was soon realized even in those early days that such limited work could not be effective in controlling, or even influencing to any appreclable degree, the outsized forces at work in the entrance and that improvement of more permanent character would be required. The first project was adopted on August 2, 1882, pursuant to the recommendations of the Board of Engineers for the Permanent Improvement of the Mouth of the Columbia River (I). This project provided for the construction of a south Jetty, 4-1/2 miles in length, lying in a generally northwesterly direction from its base at Point Adams to secure a depth of 30 feet over the entrance bar. Construction of the rubble-mound structure was initiated in April 1885 and completed, with four groins along its northerly side, in october 1895. The crest of the completed jetty sloped from 12 feet above mean lower low water at its shore end to plus 10 feet at a point $1-1 / 8$ miles from the shore, thence to plus 4 feet at its outer end. A total of 946,000 tons of stone were placed in the structure at a total cost of $\$ 1,969,000$. Although shoals marking the beginning of clatsop spit began to form along the north side of the jetty during its construction, a general improvement of depths over the bar was soon evident. By 1895 depths of 31 feet were available on an alignment winich, under the influence of the jetty, had migrated to the north about three miles. These favorable conditions were only temporary, however, as the continued northward migration of the channel by 1898 reduced depths to 29 feet and by 1901 caused further 
PHENOMENA AFFECTING IMPROVEMENT OF THE LOWER COLUMBIA ESTUARY AND ENTRANCE

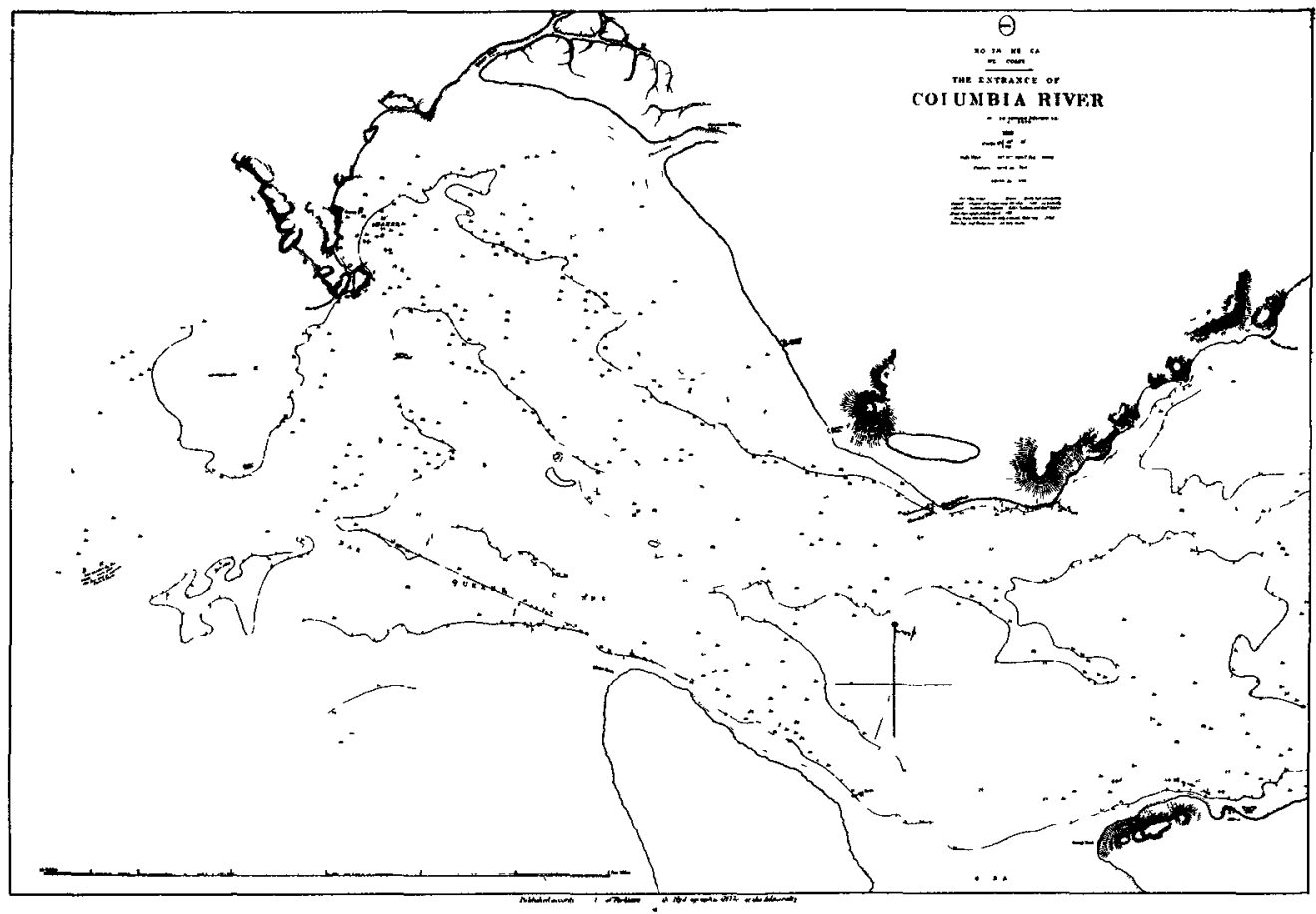

Fig. 5. Chart by Sir Edward Beloher.

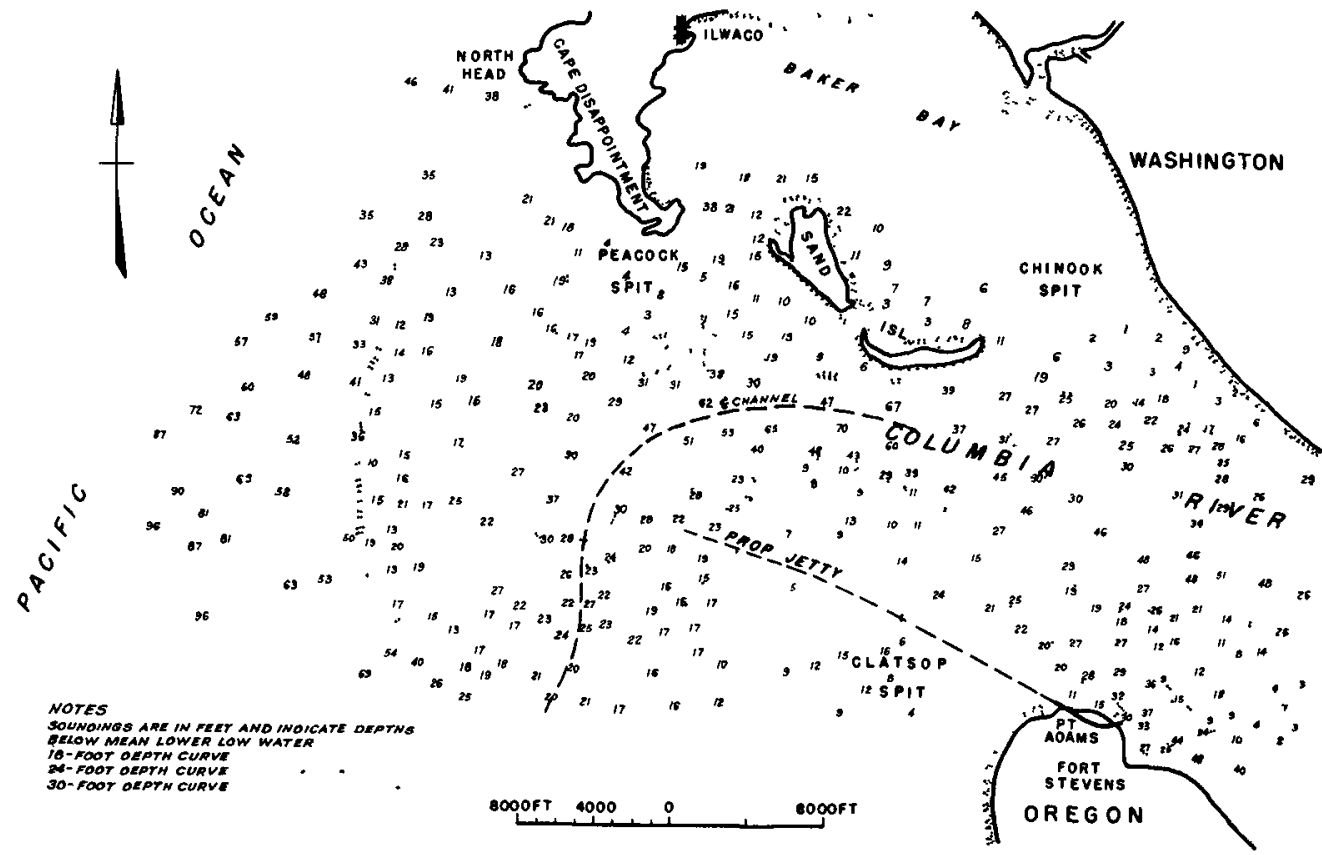

Fig. 6. Columbia entraneo - 1885. 


\section{COASTAL ENGINEERING}

deterioriation of the entrance channel until in 1902, as shown in Figure 7, there existed three entrance channels, each only about 22 feet deep. In the neantime clatsop spit had grown to form a hook-shaped island through the south Jetty at its nid-length which later extended to create a solid land connection with Point Adams.

\section{0-FOOT ENTRANCE PROJECT}

Construction Phase - In view of these deteriorating conditions and the need for increased entrance depths to furnish a margin of safety to navigation Congress, in the River and Harbor Act of March 3, 1905, adopted the recomnendations of the Board of Enginears 9 n Project for Improvement of the Mouth of Columbia River ${ }^{(2)}$ which provided for extension of the existing South Jetty, construction of a North Jetty and groins, in combination with dredging, to secure an entrance channel one-half mile wide and 40 feet deep. As the South Jetty was being extended seaward, a single entrance was restored and by 1911 a depth of 24 feet was again available across the ocean bar. As completed to a total length of 6.6 miles in August 1913, the south Jetty had an average top width of 25 feet and an elevation of plus 10 feet from the shore to the "knuckle" end of the original project, from whence the height was increased by stages to an elevation of plus 24 feet at the outer end. Construction of the North Jetty began in 1913 and by the next year, when only about 1 mile in length, entrance depths had increased to 30 feet. As constructed the North Jetty had a top width of 25 feet, sideslopes of 1 on $1-1 / 2$, and srest elevation of 28 to 32 feet above mean lower low water. Completion of the jetty to 1ts full length of 2.4 miles in August 1917 was accompanied by further improvement of entrance depths to 40 feet through a narrow bar channel. In addition to 410,000 tons of stone used for rebullding the outer end of the original South Jetty, a total of 4,427,000 tons of stone was placed in the extension of the south Jetty, at a total cost of $\$ 5,657,000$. Nearly $3 \mathrm{milli}$ ion tons of stone were used in the construction of the North Jetty at a cost of $\$ 4,319,000$.

Adjustment Phase - Completion of the North Jetty, with its positive control on flows, marked the beginning of the achievement of the long-sought goal of securing dependable depths through the entrance for navigation. By 1920 the 40-foot depth contours had retreated considerably providing an entrance channel about one mile wide and, during the next five years, further deepening occurred to make a mini- 


\section{PHENOMENA AFFECTING IMPROVEMENT OF THE LOWER COLUMBIA ESTUARY AND ENTRANCE}

mum entrance depth of 45 feet available in 1925. By 1927 minimum depths of 47 feet were available over the bar as shown in Figure 8. It is interesting to note that for the first time depths in excess of 40 feet then prevalled along the channel side of the North Jetty. However, concurrently with improvement of navigation conditions, shoals developed immediately north of the North Jetty and formed a solid land mass extending almost to its full length. Clatsop spit continued to grow until by 1931 its westward and northward extension had reduced entrance depths to about 43 feet.

Refinement Phase - Rehabilitation of the South Jetty was begun in 1931 and completed in 1936. Later in 1936 the outer 500 feet of the structure was impregnated with a hot asphaltic $\mathrm{mix}$ in an attempt to prevent disintegration at this point by heavy seas. This expedient did not prove successful and a solid concrete terminal was constructed at the outer end in 1941. Further growth of Clatsop spit was accompanied by movement of the navigation channel closer to the North Jetty and by development of increased depths along the channel side of the outer end of that structure. In an effort to prevent the continued movement of the channel to the north, four permeable dikes were constructed along the south shore of Sand Island and Jetty " $A$ ", extending southward from Cape Disappointment, was completed in 1939. In spite of this, the continued westward movement of clatsop spit was accompanied by removal of more and more of the shoal area protecting the North Jetty and some damage was caused by undercutting along the channel face of the structure. In 1939 the North Jetty was rehabilitated and a concrete terminal block placed at its outer end. Continued advance of the spit through 1951 coincided with definite movement of the 40-foot depth contour along the north side of the entrance channel to the east and south and in 1952, for the first time, an inner bar in extension of clatsop spit had formed between the jetties. Reconstruction of the south Jetty involved the placement of $4,288,000$ tons of stone in the superstructure at a cost of $\$ 4,930,000$. Rehabilitation of the North Jetty required the placement of 244,000 tons of stone and 234,000 tons of stone were used in the construction of Jetty " $A$ ", all at a total cost of $\$ 1,271,000$.

Dredging - As ample depths prevailed over the ocean bar, dredging under the 40-foot entrance project was confined to the face of clatsop spit. Amounts dredged since 1939 under that project were as follows: 


\section{COASTAL ENGINEERING}

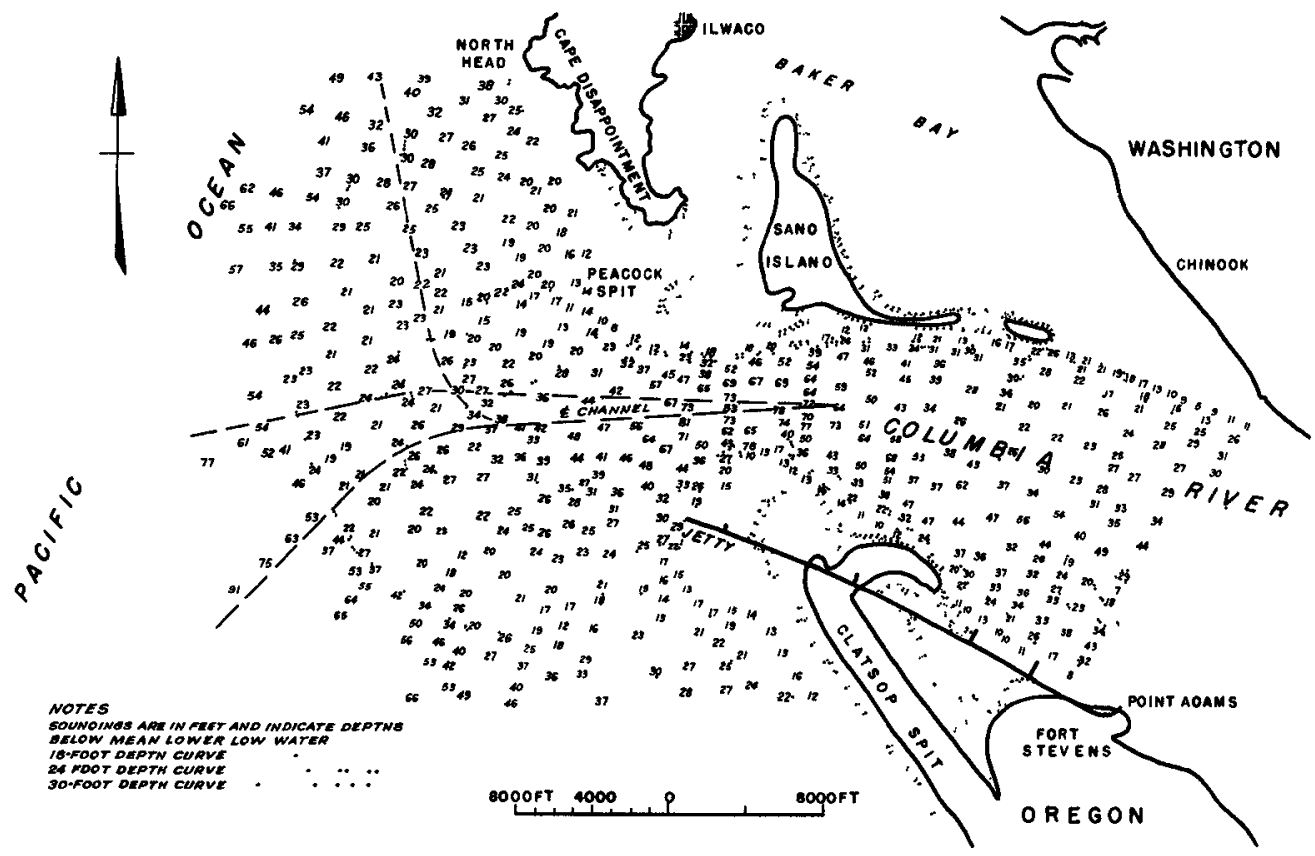

Fig. 7. Columbia entranco - 1902.

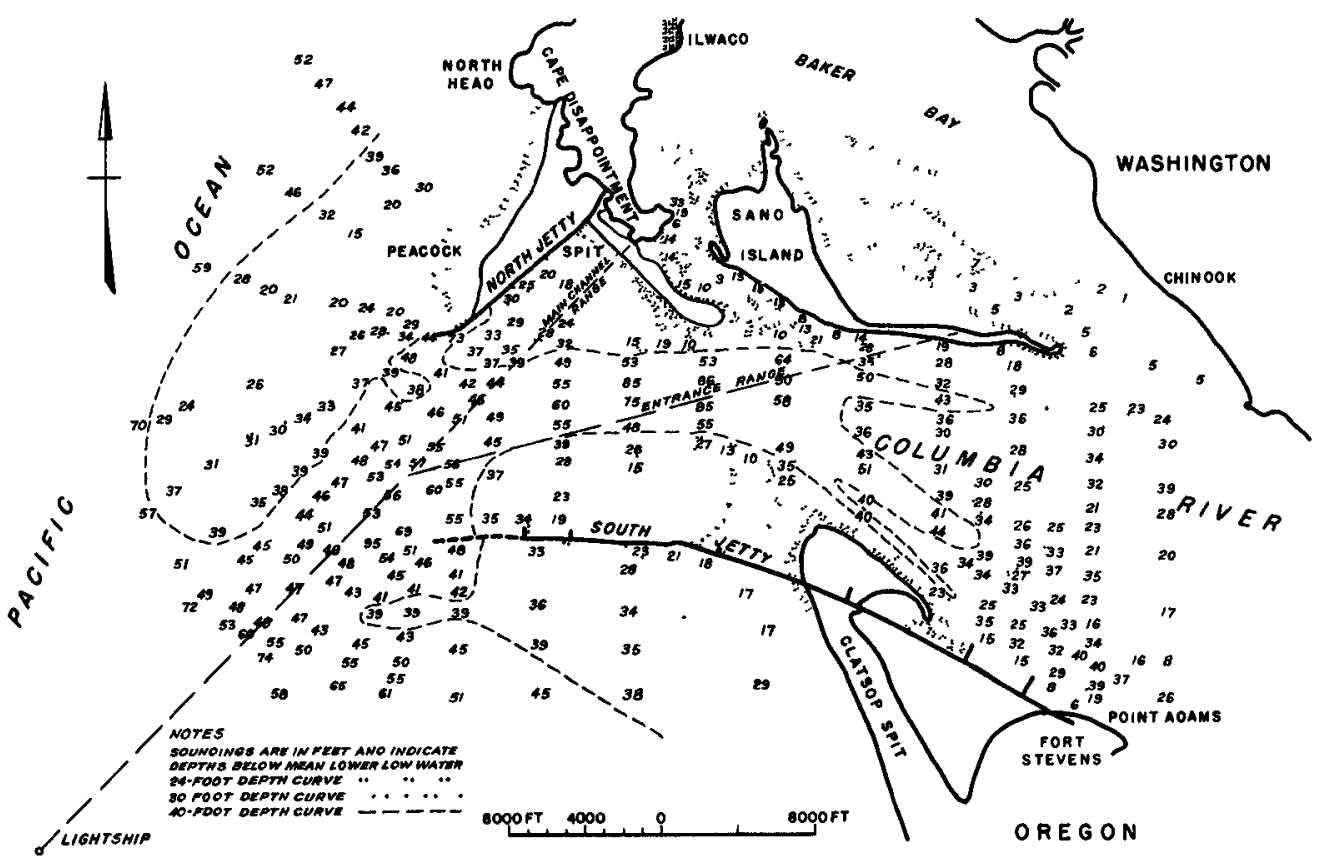

Fig. 8. Columbia entrance - 1927. 
PHENOMENA AFFECTING IMPROVEMENT OF THE

LOWER COLUMBIA ESTUARY AND ENTRANCE

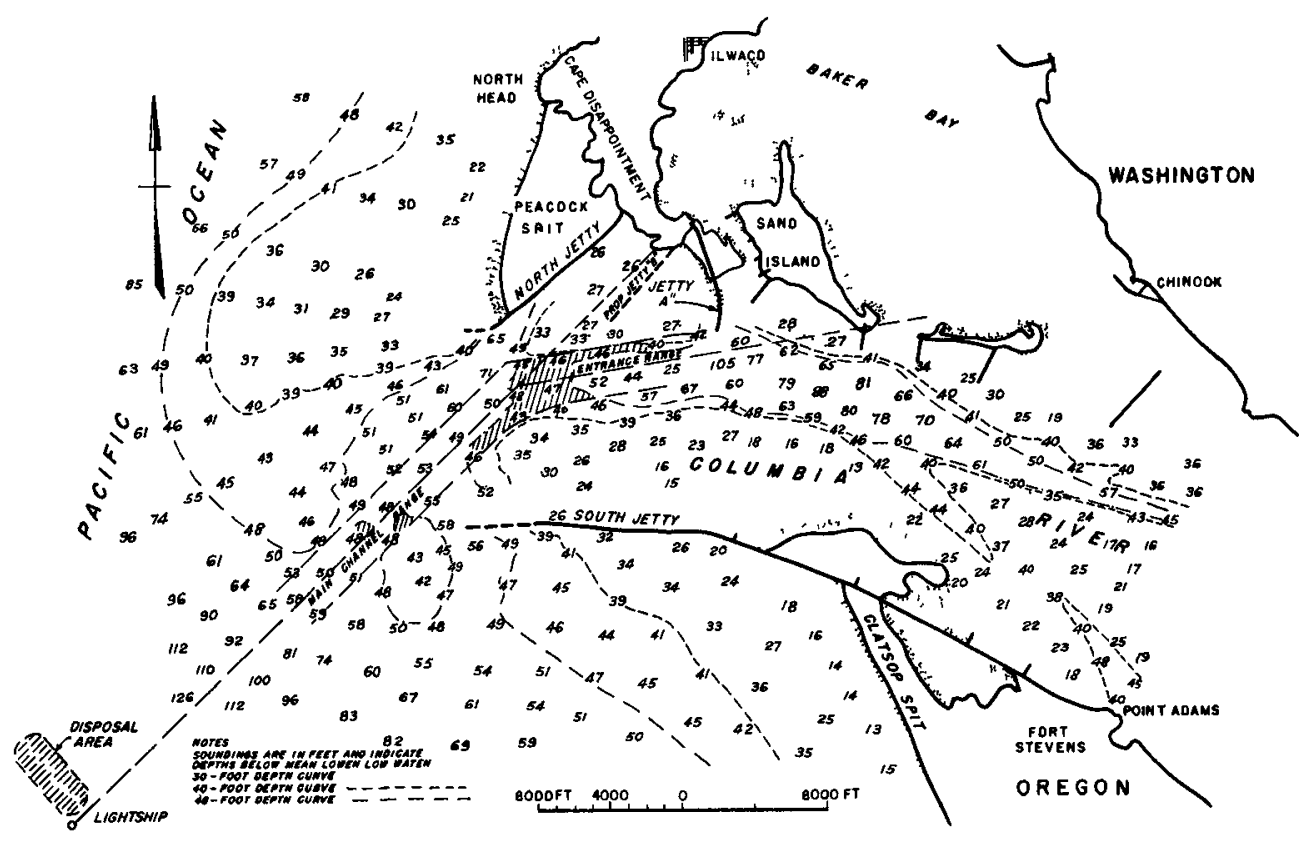

Fig. 9. Columbia entrance - 1962.

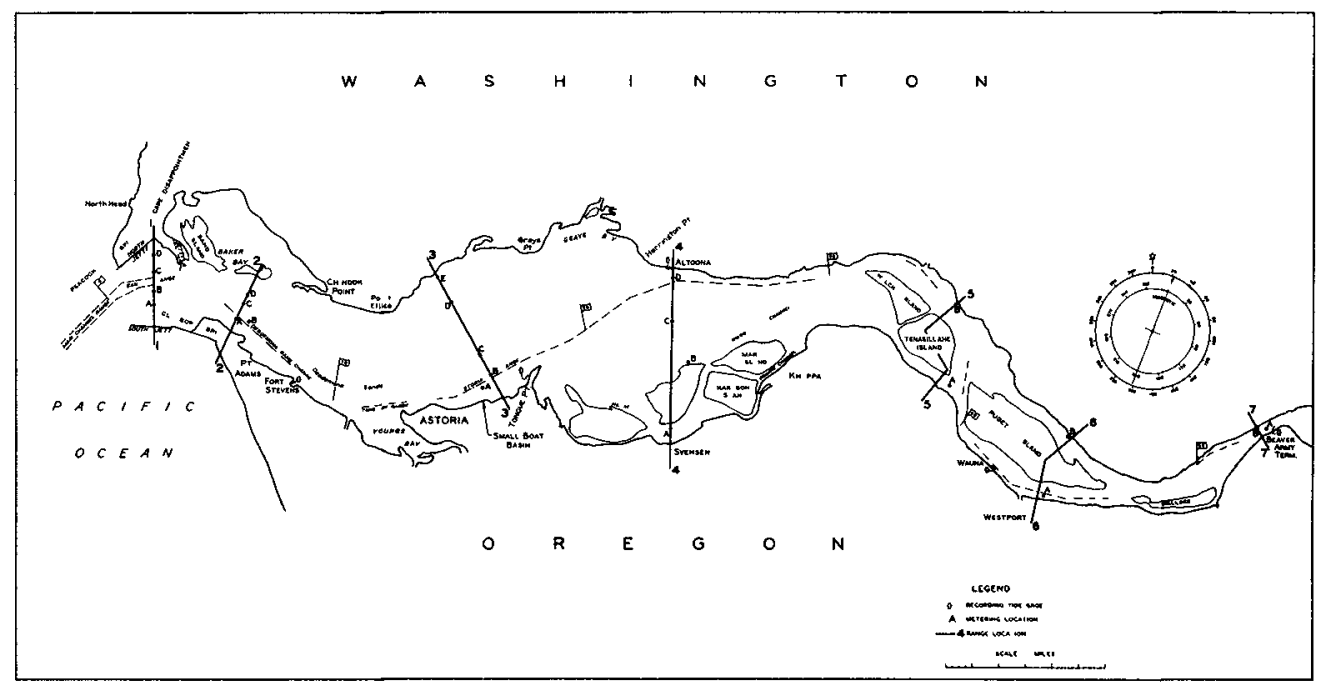

Fig. 10. Prototype measurement ranges and stations. 
COASTAL ENGINEERING

AMOUNT DREDGED

CUBIC YARDS

FISCAL YEAR

1939

1940

1941-44

1945

1946

1947

1948

$$
\begin{gathered}
501,300 \\
1,319,800 \\
\text { None } \\
393,100 \\
186,900 \\
483,000 \\
1,030,200
\end{gathered}
$$

\section{FISCAL YEAR}

1949

1950

1951

1952

1953

1954

1955
AMOUNT DREDGED

CUBIC YARDS

$$
\begin{array}{r}
1,023,800 \\
923,200 \\
1,000,300 \\
1,267,400 \\
2,796,800 \\
2,141,700 \\
1,749,300
\end{array}
$$

The full project width was sbtained only during the last three fiscal years listed above.

\section{8-FOOT ENTRANCE PROJECT}

Project Progress - To neet the needs of mistern ocean navigation Congress, in 1954, modified the entrance project to provide for minimum depths of 48 feet throughout the halfmile channel width to be secured initially by dredging and subsequently, if experience so warranted, by construction of spur Jetty "B" along the north shore, shown on Figure 9, which also shows conditions prevailing in 1962. Dredges were successful in 1956, the inttial year of dredging on the nodified project, in securing by the end of the season in October depths of 48 feet over the full channel width, in spite of heavy amounts of erratic shoaling and scouring which accompanied the dredging operations. Extremely heavy shoaling of the newly dredged channel during the following winter months, together with lack of sufficient dredging plant, resulted in the decision to concentrate the 1957 dredging effort to securing project depths throughout a channel of only 1,500 foot width. Dredging in 1957 was also accompanied by erratic shoaling and scouring over the 1,500-foot channel and was similarly followed by proportionately heavy shoaling during the ensuing winter season. Approximately $75 \%$ of the material dredged in 1956 and 1957 was disposed in an offshore area approximately one mile south of the extreme end of the south Jetty (Area A), as shown on Figure 3, with the balance disposed in deep water along the entrance range (Area B), adjacent to the inside of the North Jetty (Area C), and upriver in the vicinity of Chinook Point (Area D). Quantities dredged during these and subsequent years and the amounts of total apparent shoaling and scouring noted within the authorized channel width by frequent condition surveys are given in the following tabulation: 


\begin{tabular}{|c|c|c|c|c|c|}
\hline \multirow{2}{*}{$\begin{array}{c}\text { CAIENDAR } \\
\text { YEAR }\end{array}$} & \multirow{2}{*}{$\begin{array}{c}\text { QUANTITY } \\
\text { DREDGED, } \\
\text { 1,000 } \\
\text { C.Y. }\end{array}$} & \multicolumn{2}{|c|}{ AMOUNT } & \multicolumn{2}{|c|}{ NET } \\
\hline & & $\begin{array}{c}\text { SHOALING } \\
1,000 \\
\text { C.Y. }\end{array}$ & $\begin{array}{c}\text { SCOURING } \\
1,000 \\
\text { C. Y. }\end{array}$ & $\begin{array}{c}\text { SHOAL } \\
1,000 \\
\text { C.Y. }\end{array}$ & $\begin{array}{c}\text { SCOUR } \\
1,000 \\
\text { C.Y. }\end{array}$ \\
\hline \multicolumn{6}{|c|}{1956 and 1957} \\
\hline $\begin{array}{l}1956 \\
1957\end{array}$ & $\begin{array}{r}14,436 \\
3,909 \\
\end{array}$ & $\begin{array}{l}8,492 \\
7,279 \\
\end{array}$ & $\begin{array}{l}6,263 \\
7,436 \\
\end{array}$ & $\begin{array}{r}2,229 \\
--- \\
\end{array}$ & --- \\
\hline Total & 18,345 & 15,771 & 13,699 & 2,229 & 157 \\
\hline \multicolumn{6}{|c|}{1958 through 1961} \\
\hline 1958 & 2,603 & 3,216 & 5,942 & $-\infty$ & 2,726 \\
\hline 1959 & 2,289 & 6,146 & 3,361 & 2,785 & $\ldots$ \\
\hline 1960 & 2,286 & 5,008 & 4,048 & 960 & -- \\
\hline 1961 & $\underline{2,054}$ & 3,559 & 3,007 & 552 & $-\infty$ \\
\hline Total & 9,232 & 17,929 & 16,358 & 4,297 & 2,726 \\
\hline
\end{tabular}

Modification of Spoil Disposal Areas - Tests of pilot equipment designed to measure subsurface current directions and velocities, conducted early in 1958 in preparation for the general prototype measurement program of the following year, revealed the fact that spoil disposed in Areas $A$ and $C$ returned to the dredged entrance channel. As a consequence, disposal practices were subsequently modified so as to concentrate disposal of dredged materials in deeper water offshore (Area B) and to eliminate as much as possible the disposal of these materials south of the South Jetty and near the North Jetty. Although since that date shoaling and scouring has generally followed the previously noted pattern, the magnitude of such occurrences has been reduced somewhat from that experienced in previous years as shown above.

\section{Rehabilitation of Entrance Structures - Rehabilitation} of Jetty " $A$ " in 1961 involved the placement of about 214,000 tons of stone at a cost of about $\$ 814,000$. In that same year, 213,460 tons of stone were used in rehabilitation of the upper portion of the South Jetty between the land connection with Point Adams and the "knuckle" at a cost of $\$ 2,328,000$. Rehabilitation of the South Jetty seaward of the "knuckle" involving the placement of 268,000 tons of stone is scheduled for completion in 1963. 


\section{COASTAL ENGINEERING}

\section{PAST CONCEPTS OF CONTROLLING PHENOMENA}

\section{APPROACH TO PAST CONCEPTS}

Any discussion of past concepts of phenomena controlling the regimen of the lower Columbia Estuary and Entrance as related to the constructed improvements should, of course, recognize the state of knowledge prevailing at that time. Engineers had little but readily observable conditions and apparent reactions of surface currents to obstacles to guide their thinking, planning, and design, of improvements, since estuarine instrumentation as it is known today did not then exist. Hence it is small wonder that some works constructed under these circumstances failed to yield the desired results. The surprising thing is that many of these works did somehow accomplish their mission, perhaps not in the exact manner predicted, and have nevertheless survived to this day as monuments to the integrity and ingenuity of their planners. Accordingly, as we review these past accomplishments in the light of present knowledge, engineers of today should feel quite grateful and, indeed humble, for the advancement in technology which alone is responsible for their more enlightened position.

\section{PAST EXPERIENCE}

With little to guide their efforts other than the observed conditions in the natural estuary and entrance, it was apparent to engineers charged with planning the columbia Entrance structures that in order to provide a dependable channel, the waters of the entrance area should be confined to an area smaller than then existed in nature. To effect such an accomplishment a south Jetty was constructed with its base at Point Adams which, while temporarily improving entrance conditions during the subsequent period of estum arine adjustment, did not fulfill the needs of then-existing navigation as depths over the ocean bar had not been permanently improved by this expedient. In view of this engineers then studied the bankline geography of the lower estuary and concluded that further confinement of entrance flows should be effected by opposing jetties spaced about two miles apart at their ends, roughly the minimum distance between banklines in the lower estuary $(2)$. Accordingly, the south Jetty was extended and a North Jetty construated. Although some improvement was effected by the extension of the South Jetty, this betterment of conditions was relatively minor and of a tentative nature only. It was not until the North Jetty had 


\section{PHENOMENA AFFECTING IMPROVEMENT OF THE LOWER COLUMBIA ESTUARY AND ENTRANCE}

been constructed that a truly dependable channel was made available in the Columbia River entrance. Although everchanging controlling depths over the entrance bar were achieved in different phases of estuarine adjustment following the completion of the North Jetty, these depths were much greater than those which previously existed. As a result, by confinement of entrance flows to a relatively smaller area, engineers achieved a "breakthrough" in their efforts to control depths over the entrance bar.

\section{PAST CONCEPT AS DEVELOPED BY EXPERIENCE}

Thus the success gained by confinement of entrance flows supported the conclusion that in order to achieve greater entrance depths it was only necessary to confine flows to the extent required. Although recognizing that there existed a number of observed phenomena such as formation of shoals in unexpected places, which somehow did not conform to this concept, these engineers were primarily concerned, and justifiably so, with net results as measured by past accomplishments. As a consequence, the theory of confinement of flow was accepted by these engineers as a basic principle in the planning, design and construction of estuarine improvements.

1932 Current Measurements - Notwithstanding the apparent validity of the theory of flow confinement there prevailed some question whether this theory properly integrated all factors and forces in estuarine areas. Consequently in 1932 the Corps of Engineers (3) undertook a program of prototype measurements at five stations across a range loated some 5 miles above the ends of the jetties. Over 5,600 individual current meter observations were nade at several depth levels at these stations during three different stages of upland discharge. Although no instruments were specifically employed for the purpose of determining sub-surface current directions, the measurenents taken were interpreted to indicate that mean ebb tide velocities were greater than flood tide velocities for all stages of the upper river and, during freshet stages, were much stronger. Also at high river stages, ebb bottom veloaities were much higher than flood bottom velocities for all percentages of time. At interm mediate river stages bottom velocities were lower than at high stage with ebb bottom velocities predominating for about half the measurements. At low river stages flood bottom velocities were generally predominate. Considering the magnitude of ebb bottom velocities as compared to flood bottom velocities and their assuned greater transporting 


\section{COASTAL ENGINEERING}

power, it appeared evident at that time that the ebb flow was sufficient to maintain a channel between the jetties of at least 40 feet deep at mean lower low water and that no further contraction of the entrance appeared necessary for satisfactory channel maintenance. Thus, the results of the 1932 current measurement program were interpreted as confirming the theory of flow confinement as applied to improvaments in the Columbia Estuary and Entrance.

Ietty "A" - Notwithstanding the indication revealed by the 1932 current measurements that further contraction works would not be necessary to secure project depths, Clatsop spit continued to advance to the northwest, crowding the entrance channel against the North Jetty and reduaing the available depths in a channel which was at that time assuming an undesirable alignment. To correct this condition Jetty "A" was constructed in 1938 and 1939 to further confine flows in the entrance area. Although Jetty "A" provides a degree of protection to vessels using the west Baker Bay channel against winter winds and waves, this structure, even in combination with the concurrently constructed sand Island dikes, has had little beneficial influence on navigation depths or conditions through the lower Columbia Estuary or Entrance.

Jetty "B" - Although the failure of Jetty "A" to produce the desired channel control could not be explained at that time, the validity of the theory of flow confinement was still accepted, although to a somewhat lesser degree, by engineers as late as the early 1950's when planning for the 48-foot entrance channel was initiated. Accordingly, as part of the 48-foot project, Jetty "B", to be located between the North Jetty and Jetty "A", was recommended and authorized in 1954 as a structure to supplement and enhance the confining influence of Jetty " $A$ ", if initial operations to secure the 48-foot entrance channel proved impracticable. Subsequent events and almost explosive expansion of knowledge regarding estuarine phenomena have cast considerable doubt on the value of the proposed Jetty " $B$ " as a regulating structure and, consequently, no further action has been undertaken by the Corps of Engineers leading toward its construction.

\section{MODERN CONCEPTS OF CONTROLLING PHENOMENA}

\section{APPROACH TO MODERN CONCEPTS}

Much credit should be given to the Corps of Engineers ' Committee on Tidal Hydraulics and to the Waterways Experiment station for their pioneering efforts and studies which have led to a broadening of engineering knowledge of character and 


\section{PHENOMENA AFFECTING IMPROVEMENT OF THE LOWER COLUMBIA ESTUARY AND ENTRANCE}

magnitude of forces controlling the regimens of estuaries and their entrances. Early hydraulic model studies at the waterways Experiment station included a model of the Savannah Estuary and Entrance (Georgia) and, as was the practice at that time, fresh water was employed throughout the model system. Considerable difficulty was initially experienced in attempting to verify current measurements made in the model with those observed in the prototype. All efforts to secure accurate verification of the model failed until someone suggested that salt be added to the ocean portion of the model in the amount necessary to simulate salinity conditions in the prototype ocean. When this was done, verification was a relatively easy task as the model, thus operated, completely and accurately reproduced observations of current direction and velocity noted in the prototype. This "breakthrough" in model techniques led to study and definition by many engineers and scientists of the important role that salinity intrusion plays in the development of forces controlling estuarine environment. These studies and companion investigations of related phenomena by others during the last 15 years have produced a new concept of estuarine phenomena which has given the waterways engineer a more complete and accurate understandlng to the end that 1 is no longer necessary to resort to a trial and error approach to estuarine improvements. Although this new concept has completely revolutionized all past thinking and has given birth to the embryonic science of tidal hydraulics, investigations of all estuarine phenomena are being prosecuted at an ever-expanding rate under the favorable technological climate prevailing in the world today. Hence, new discoveries will be made and new techniques will be developed which will further assist the engineer of the future to solve estuarine problems more completely than is now possible.

\section{SALINITY INTRUSION}

Although of extreme importance in the development of the estuarine regimen, the role that salinity intrusion plays in this development has to date been only broadly defined. Schultz and simmons $(4)$ point out that engineers concerned with the solutions of problems in estuarine environments have become keenly aware in recent years that the amount of fresh water discharged into an estuary, and the degree to which it mixes therein with the salt water of the sea, are major factors in establishing the hydraulic and shoaling regimens of the estuary. The presence in estuaries of water of variable density causes marked differences in the magnitudes, distributions, and durations of the currents, as compared to those of 


\section{COASTAL ENGINEERING}

a single density system. As a result of the density difference between the heavier salt water at the seaward end of the estuary and the fresh water at the upstream end, each type of water tends to assume a rough wedge shape with the base of the wedge at the source. The interface of (or line of demarcation between) the salt and fresh water may vary from well defined to almost obscure, depending on the degree of mixing of the salt and fresh water in any given estuary. Where mixing is slight the transition from fresh to salt water is well defined and occurs within a small percentage of the channel depth. On the other hand, where the mixing is appreciable no definite interface of the salt and fresh water exists except in isolated instances. For convenience, the degree of mixing may be classed into three broad categories of highly stratified, partly mixed, and well mixed, with the transition from one type of mixing to another being gradual instead of well defined. The most significant effect of salinity intrusion, thus defined, is the creation of density currents in estuaries which cause the bottom flood currents to predominate over the bottom ebb currents by increasing the velocity and duration of the former and decreasing the velocity and duration of the latter. The resulting net upstream movement of bottom currents within the saline region of the estuary constitutes an effective trap for sediments on and near the bottom, preventing their movement to the sea and causing the bottom to be shoaled and unstable. From their studies schultz and simmons arrived at the following general conclusions:

a. The degree of mixing of salt and fresh water in estuaries plays an important role in the establishment of their hydraulic regimens. As the shoaling regimens of some estuaries are related directly to their hydraulic regimens, it follows that the degree of mixing also plays an important role in establishing their shoaling regimens.

b. Because of incomplete mixing of salt and fresh water in estuaries, the predominance of flow in the bottom strata is almost always upstream while that in the surface strata is downstream; the degree of such predominance is dependent on the degree of mixing, being most prominent in the highly stratified estuary and least prominent in the wellmixed type.

c. Changes in upland discharge, tidal prism, and physical configurations of estuaries will frequently change the degree of mixing of salt and fresh water therein and thus affect such important features as the vertical distribution 
of current velocities, the direction and degree of flow predominance, the amount of shoaling, and the location of major shoal areas.

d. As lightweight sediments are supplied to estuaries principally through the medium of upland discharge, it follows that such discharge plays a dual role in estuarine sedimentation.

e. The magnitude of changes in upland discharge into estuaries usually far exceeds that of changes in tidal prism or physical conflguration. For this reason, and because upland discharge is of primary importance, it follows that major changes in upland discharge should be accomplished only after consideration of all probable effects.

Continuing Research on Salinity Intrusion - An analytical investigation of salinity intrusion and ralated phenomena was initiated by the Committee on Tidal Hydraulics in January 1954. This general investigation was designed to deterinine for conditions of open channels subject to salt water intrusion and tidal oscillations from the sea the following foux aspects of the phenomena: (a) The extent of salinity intrusion and the mean salinity distribution, (b) the vertical mixing of fresh and salt water and the resulting vertical salinity distribution, (c) the vertical distribution of current velocities as affected by salinity distribution, and (d) the movement and deposition of sediments as affected by density-current phenomena. On the basis of studies undertaken on phase (a) of this general invastigation, Ippen and Harleman $(5)$ indicate that it is possible to make quantitative predictions regarding salinity intrusions in partialiy or well-mixed estuaries of essentially uniform cross section without prior knowledge of any existing salinity conditions. Further, the factors which cause changes in salinity intrusions have, for the first time, been quantitatively evaluated. Thus by means of intrusion equations, the effect of changes in the fresh water discharge, channel depth, etc., can be predicted. Of even greater importance is the possibility that the diffusion and tidal parameters developed in this study will have important significance in understanding the intrusion mechanics of estuaries of non-uniform geometry. Analyses will be made of phases (b), (c), and (d) of this investigation in the light of findings of studies of phase (a) as may be applicable. 


\section{COASTAL ENGINEERING}

\section{SHOALING PROCESSES}

Mush renains to be learned regarding the processes involved in the formation and stabilization of shoals in estuarine channels. In 1957 the Committee on Tidal Hydraulics launched a broad program of studies considered necessary to develop essential knowledge of these processes. The different phases of work contemplated under this program are sumnarized as follows:

Basic Laws for Movement and Deposition of Muddy Sediments - Since most estuarine shoals in the United States are composed of muds rather than sands a contract has been made with the University of California to study the rheological properties of consolidating sediments. Natural sediments from a number of estuaries are being furnished to the University as a basis for the studies.

\section{Effects of Repetitive Scour and Deposition on Sedimen-} tation - As it appears that successive scour and deposition of sediments may play an important role in shoaling processes, early flume tests to determine the significance of these factors are planned.

\section{Techniques for Radioactive Tracing of Sediment Action -} These techniques offer a great potential in the development of knowledge in shoaling processes, making it mandatory that their use be encouraged in connection with specific investigations and that consultation and advice be extended to those engaged in this work. Field tests planned by the District Engineers, Galveston and Norfolk, will be alosely followed.

Development of In-Place Turblaity Meter - Because of the great areas embraced by most estuaries and the constantly changing conditions of tide and fresh-water inflow, it is apparent that complete and simultaneous coverage of such systems for measurements of suspended sediment concentrations, with only approximately accurate results, will yield much more valuable information than will long-term coverage and highly accurate results. Available evidence indicates that al instrument operating on the basis of light extinction as a measure of turbldity may fulfill these needs. Development of such an instrument is under way at Johns Hopkins University.

Flocculation - Flocculation of suspended and dissolved solids plays an important role in shoaling processes as sea water is an efficient flocculating agent, but little work of scientific value has yet been accomplished to evaluate its 


\section{PHENOMENA AFFECTING IMPROVEMENT OF THE LOWER COLUMBIA ESTUARY AND ENTRANCE}

significance. A comprehensive literature survey of this subject has been made and a report thereon completed. Recomnendations for further work in this field are now under review and it is probable that further research will shortly be initiated.

Stabilization of Deposits - The physical and chemical changes which occur in sediments after deposition appear important to an over-all appraisal of the matter of shoaling processes. A literature survey of this subject has been completed and additional research is forthcoming.

Analysis and Correlation of Prototype Data - Proper analysis and correlation of existing prototype hydraulic, hydrographic, and other data will reveal certain relationships among estuaries which should lead to a better understanding of the over-all subject of shoaling processes. Data on important estuaries are now being assembled and analyzed and it is anticipated that direct comparisons and correlations should reveal definite characteristics.

Shoaling in Slips and Tributary Channels - It is anticipated that test facilities for general investigations of hydraulic and shoaling phenomena in slips and tributary channels will shortly be constructed as additions to existing hydraulic models at the Waterways Experiment station and tests initiated to determine the factors involved.

Classification of sediments - Proper classification of the sediments which contribute to shoaling of the different estuaries in the United States is of importance from the viewpoint of a comprehensive understanding of shoaling processes. This effort is being carried out concurrently with the analysis and correlation of prototype data previously described.

\section{LITTORAL PROCESSES}

Waves of all character and magnitude breaking on a coastline generate movements of beach materials in the alongshore component direction of the generating waves. These movements establish the littoral regime of the shoreline and the intensity of these movements determine the quantity of material or littoral drift moving past a point on the shoreline. As, during the course of an extended period of time, waves attack a shore generally from one predominant direction, so too will the littoral movements of material passing a point on that shore move in one predominant direction parallel to the coast. 


\section{COASTAL ENGINEERING}

Just as waves also attack this shore from other directions over an extended period of time, though less predominately from those directions, so too will there be littoral movements past the point which may be in a direction opposite that of the predominate littoral drift. Thus, from a point along a shoreline, such as the entrance to an estuary, the total quantity of littoral material in movement is the sum of all littoral movements in both the up-coast and down-coast directions. Both of these material movements contribute to shoaling in major estuarine entrances. They also affect the delicate balance between erosion and accretion of the shoreline. In instances where littoral drift is intercepted by coastal structures such as groins or jetties, the shore updrift of these structures will grow seaward to a point, fed by the cessation of the littoral movement, while the shore downdrift from the structures will recede, being starved by the intercepted littoral drift.

\section{PROTOTYPE MEASUREMENT PROGRAM OF 1959}

\section{BACKGROUND}

In view of difficulties experienced in maintenance of the 40-foot entrance project resulting from the continual encroachment of clatsop spit shoals on the adopted channel alignment, the problem at the Columbia River Entrance was reapproached in 1956 in the light of new concepts and expanding knowledge of tidal hydraulic phenomena concurrently with initiation of work on the newly authorized 48-foot entrance project. In making this new approach the advice and guidance of the Committee on Tidal Hydraulics formed the basis for an intensive investigation of several aspects of the problem. As the initial step in this investigation the Committee recommended that a program of prototype measurements of current velocity and direction, as well as salinity, be undertaken to broadly define the density current regime established by environmental river, ocean and hydrographic conditions prevailing in the lower estuary. With effects of density currents thus defined it was the view of the committee that any additional structural measures designed to reduce shoaling in the entrance area, such as Jetty "B", could be properly analyzed and evaluated in a hydraulic model study.

\section{GENERAL SCOPE OF PROGRAM}

In order to achieve the above goal it was necessary that the program provide data sufficient to meet the design and 


\section{PHENOMENA AFFECTING IMPROVEMENT OF THE LOWER COLUMBIA ESTUARY AND ENTRANCE}

verification needs of a hydraulic model study. To this end the program required three cycles of measurements to obtain data for conditions of low, normal, and high river discharge, each cycle including observations of current direction and velocity for a continuous full tidal period of about 25 hours at 23 stations located along seven ranges across the lorer 52 miles of the estuary, shown in Figure 10. At each station current velosity and direction measurements were taken at 30minute intervals at the surface and near the bottom and at the intervening quarter-points of depth. Initially, simultaneous observations were made at one station on each range for a continuous period of about 25 hours to establish the relationship between the ranges. This was followed by simultaneous observations at all stations on each range until all observations had been obtained. Salinities and temperatures were also observed throughout the vertical at each station concurrently with the measurements of currents and directions. This program, due to its magnitude and the complexities involved in instrumentation, administration and operation, not to mention the trying conditions of weather and heavy seas, represented a monumental task. A total of approximately 26,000 observations were taken during the three sycles of measurements. However, in spite of the magnitude of work involved and the difficulties experienced, rellable measurements were secured.

\section{PROGRAM INSTRUMENTATION}

Velocity - Azimuth - Depth Assembly - Equipment being tested by the United State Geological Survey to measure tidal flow was used as a guide in the prototype measurement program for the development of an instrument designed to measure subsurface current velocity and direction, as well as depth of the instrument above the bottom. This instrument consisted of a transducer for a Raytheon Fathometer, mounted in the bottom of 140-pound streamline brass weight with fins, suspended on the bottom of a Price current meter hanger bar. Also mounted in the weight was a Magnesyn compass transmitter which monitored on a remote panel the direction in which the assembly was facing as deflected by the current. - A seven-conductor, pancake swivel was mounted between the current meter hanger bar and the seven-conductor, 1/4" diameter, suspension cable. The assembly as finally developed and used in the program is shown in Figure 11 .

Salinity - Temperature Assembly - Although consideration was given to the advisability of taking water samples at the five elevations of each station and determining salinity by 
COASTAL ENGINEERING
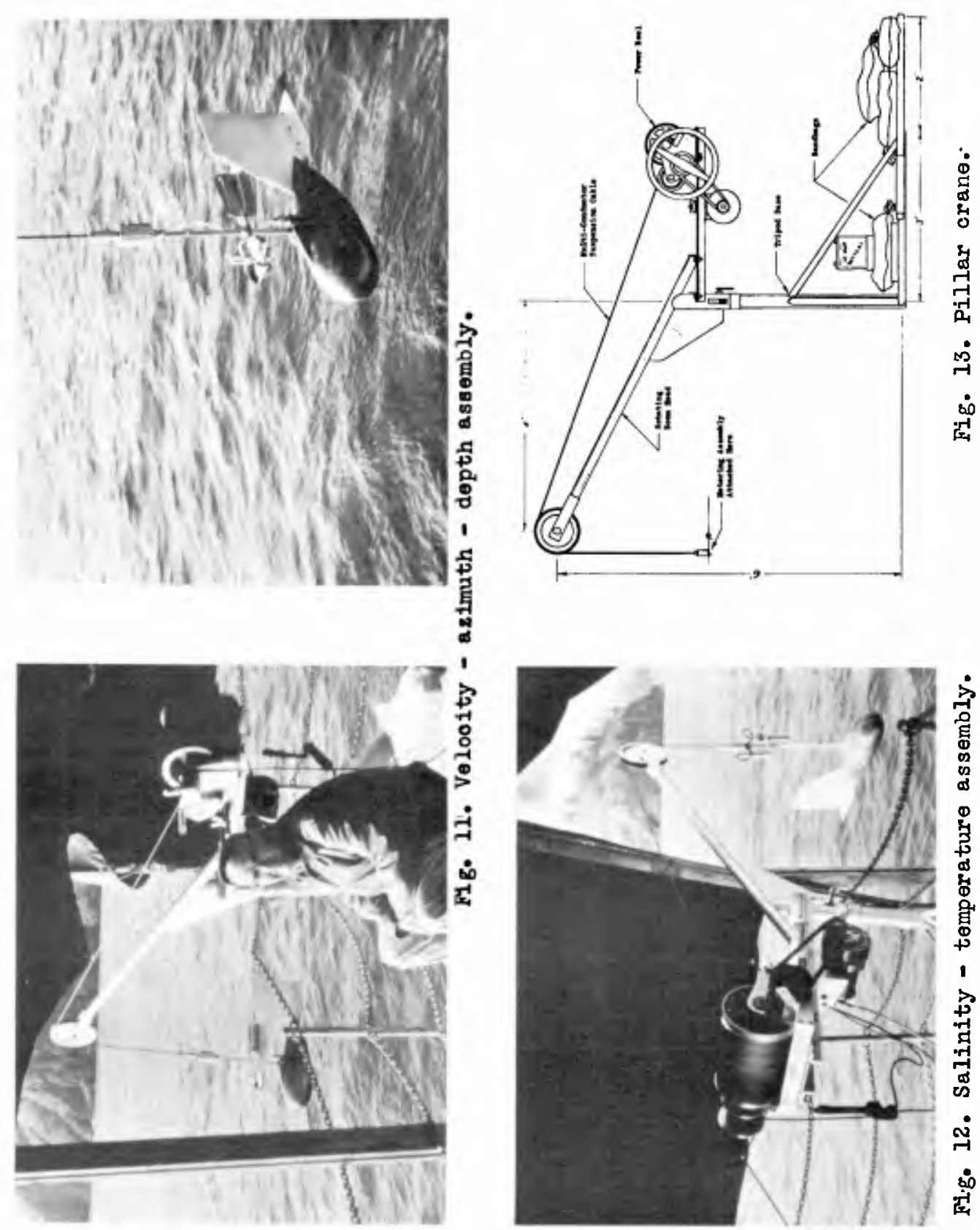


\section{PHENOMENA AFFECTING IMPROVEMENT OF THE LOWER COLUMBIA ESTUARY AND ENTRANCE}

laboratory tritration procedures, it was felt that, in the interest of reducing the workload, a less exact method of measuring salinity would suffice for the needs of the data collection and analysis program. It was also considered advisable to secure concurrent measurements of water temperature. To meet these requirements a conductivity cell with remote-reading resistance indicator was used to measure salinity and a temperature cell, together with wheatstone-balanced bridge, was used to obtain temperatures. The conductivity and temperature cells were nounted on a bracket above a 140-pound brass weight and short leads from the cells were connected to leads from the suspension cable inside a short stainless steel hanger that was clamped to the lower end of the suspension cable, as shown in Figure 12. The soldered connections were embedded in a hard, waterproof plastic filler. A seven-conductor suspension cable identical to that used for the velocity-azimuth-depth assembly was employed.

Pillar Crane - As the metering and salinity-temperature assemblies were to be used over the sides of small boats, a special crane was designed and fabricated to raise the bottom of the assembly weights 30 inches above the boat deck and far enough away from the side of the vessel so that the danger of striking the assembly instruments against the boat hull would be minimal. Pipe was used for the main structural members of the pillar crane shown in Figure 13.

Other Equipment - In addition to 12-volt batteries for each metering vessel, one complete set of current metering and salinity - temperature assemblies, and pillar crane were kept in readiness for use. Automatic tide gage recorders were maintained at strategic points in the lower estuary to record tidal stage variations during the data measurement periods.

\section{PROGRAM ADMINISTRATION}

General - Administrative tasks associated with the program included the procurement of necessary equipment, rental of vessels, training of equipment opérators and coordination of program details with fishery and navigation interests.

Procurement of Eguipment - Assemblies and pillar cranes previously described were obtained by contract with local manufacturers. Small items, including repair parts and flashing lights for buoys, as well as battery chargers, were 


\section{COASTAL ENGINEERING}

obtained by direct purchase. Storage batteries were rented for each of the measurement periods. All equipment was assembled at the Government Moorings in Portland prior to movement by truck to the small-boat basin at Astoria winich served as the field headquarters for the program. specifications were prepared to meet the particular requirements of the control boat, the master metering boat, and four metering boats. These vessels were hired through normal contractual procedures on an hourly rental basis.

Operator Training - Professional engineers and engineer technicians from the Engineering Division of Portland District were selected as equipment operators and indoctrinated by means of a special training program. Each operator was furnished a 20-page brochure describing the purpose of the prototype measurement program and related administrative and technical details, prior to a general orientation session to insure a thorough understanding by all of their specific duties. This was followed by a 4-hour session in which each operator was taught how to assemble, operate, and maintain each item of measuring equipment.

\section{Coordination - Discussions were held with the United}

states Coast Guard to determine the type of buoy most desirable to mark the location of each measurement station in the lower estuary, and to insure the availability of such buoys and needed appurtenant equipment. At the request of the Columbia River Fisherman's Protective Association, arrangements were made to forego the use of buoys at Stations $C$ and $D$ on Range 2 to eliminate interference with fishermen's nets on established drifts and to remove and replace buoys at Stations $D$ and $\mathbf{E}$ on Range 3 during and after the August fish runs. Some minor shifting of station locations in the back channels was made at the suggestions of tug and barge operators to avoid accidental removal of buoys by log tows. The Columbia River Bar Pilots Association was notified of proposed activities and the Coast Guard was furnished the latitude and longitude of each buoy for publishing in its notice to mariners well in advance of the placement of buoys. 


\section{PHENOMENA AFFECTING IMPROVEMENT OF THE LOWER COLUMBIA ESTUARY AND ENTRANCE}

\section{PROGRAM OPERATION}

Field operations, with the attendant requirement for extreme accuracy and timing of observations, occasionally In the face of adverse weather and wave conditions, represented the most difficult phase of the measurement program. Initial operations involved the placement of first class can buoys by the Coast Guard early in April 1959 to mark the location of the neasurement stations.

Distribution of Vessels - Four equipment operators were assigned to each of the $\mathbf{s i x}$ vessels providing two 2-man operator crews for alternate 12-hour shifts throughout each 8-day measurement cycle. The control boat, the SUJAN, in addition to representing an imnediate source of supply of spare equipment and the means for supervision and control of operations, was also used to ferry operator crews to and from shore bases established at Fort Stevens, Astoria, Svenson, Knappa, and Westport for the purpose of reducing the time required for changing shifts. Station A, Range 3, the master metering station, was occupied by the metering boat, CATANA, continuously throughout each 8-day measurement cycle. The four other metering boats, the MORNING STAR, ROSIE, MARY $K$, and MY BOAT, were phased among the remaining 22 stations to obtain combinations of 25-hour measurements at each station as shown in the following tabulation:

\section{DISTRIBUTION OF METERING BOATS}

\begin{tabular}{rllllll}
\hline $25-H O U R$ & $:$ & \multicolumn{5}{c}{} \\
METERING & $:$ & BOAT AND STATION OCCUPIED & \\
PERIOD & $:$ CATANA & MORNING STAR & ROSIE & MY BOAT & MARY K \\
& & & & & & \\
\hline & & $3-\mathrm{A}$ & $3-\mathrm{C}$ & $3-\mathrm{B}$ & $3-\mathrm{D}$ & $3-\mathrm{E}$ \\
1 & $3-\mathrm{A}$ & $1-\mathrm{A}$ & $1-\mathrm{B}$ & $1-\mathrm{C}$ & $1-\mathrm{D}$ \\
2 & $3-\mathrm{A}$ & $2-\mathrm{A}$ & $2-\mathrm{B}$ & $2-\mathrm{C}$ & $2-\mathrm{D}$ \\
3 & $3-\mathrm{A}$ & $4-\mathrm{A}$ & $4-\mathrm{B}$ & $4-\mathrm{C}$ & $4-\mathrm{D}$ \\
4 & $3-\mathrm{A}$ & $5-\mathrm{B}$ & $5-\mathrm{A}$ & $6-\mathrm{A}$ & $6-\mathrm{B}$ \\
5 & $3-\mathrm{A}$ & $5-\mathrm{B}$ & $6-\mathrm{A}$ & $7-\mathrm{A}$ & $7-\mathrm{B}$ \\
6 & $3-\mathrm{A}$ & $4-\mathrm{D}$ & $2-\mathrm{C}$ & $5-\mathrm{B}$ & $7-\mathrm{B}$ \\
7 & & & & & & \\
\hline
\end{tabular}




\section{COASTAL ENGINEERING}

Observations - Measurements of current velocity and direction, salinity and temperature at five different levels were made every half hour at each station. These levels were located 3 feet below the water surface, 2 feet above the bottom, and at the intervening $1 / 4,1 / 2$, and $3 / 4$ depth levels.

Cycles of Measurement - The initial cycle of measurement was undertaken from May 5 through May 13, 1959, a period of normal river flow, when the discharge ranged from 365,000 to $404,000 \mathrm{cfs}$ in the lower estuary. The second cycle of measurement was accomplished between June 16 and June 24, 1959, a period of high river flow, when the discharge ranged between 532,000 and 577,000 cfs. The final cycle of measurement was made between september 15 and september 23, 1959, a period of low river flow, when the discharge ranged between 153,000 and 214,000 cfs.

\section{ANALYSIS OF PROTOTYPE DATA}

General - An office analysis of observed prototype data was undertaken by the District Engineer, Portland, and a record of all observations obtained and his analyses of these data are contained in a four-volume manuscript report (6) which provides the most complete source of observed data relating to the current, salinity and temperature regimes of the lower estuary and entrance. Due to weather and sea conditions, which precluded the undertaking of a program of measurements near the point where clatsop shoals encroach upon the entrance channel, all observations were made upstream from this problem area. While the measurement program did not reveal conditions prevailing in that area, it did show the vagaries of currents and other measured phenomena throughout other portions of the lower estuary and, thus, provided data for competent verification of a hydraulic model of the entrance and lower estuary. In such a model physical phenomena contributing to shoaling in the problem area are now in the process of being observed, understood, and analyzed to the extent feasible by tests of possible structural expedients.

Flow Predominance - In analyzing observations of current direction and velocity, plots similar to that shown in Figure 14 were prepared for each station. Changes in current 


\section{PHENOMENA AFFECTING IMPROVEMENT OF THE LOWER COLUMBIA ESTUARY AND ENTRANCE}

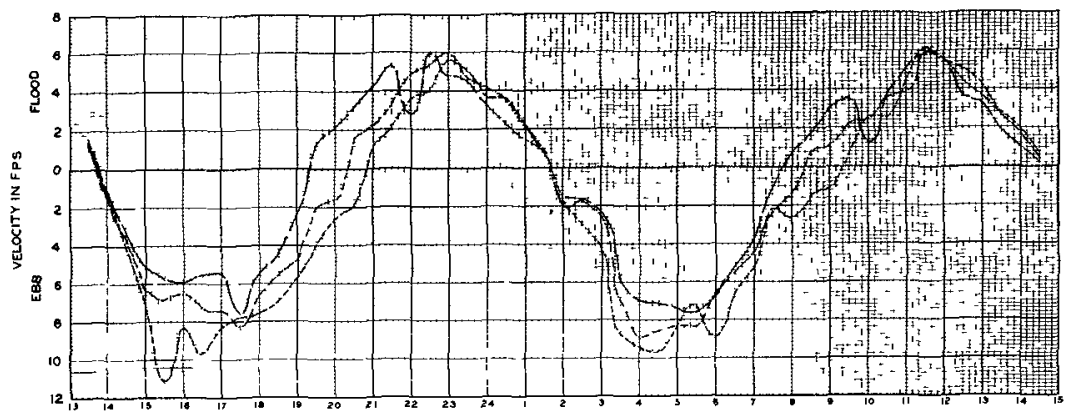

MANGe du STATION E STARTING DATE IBSEP1959
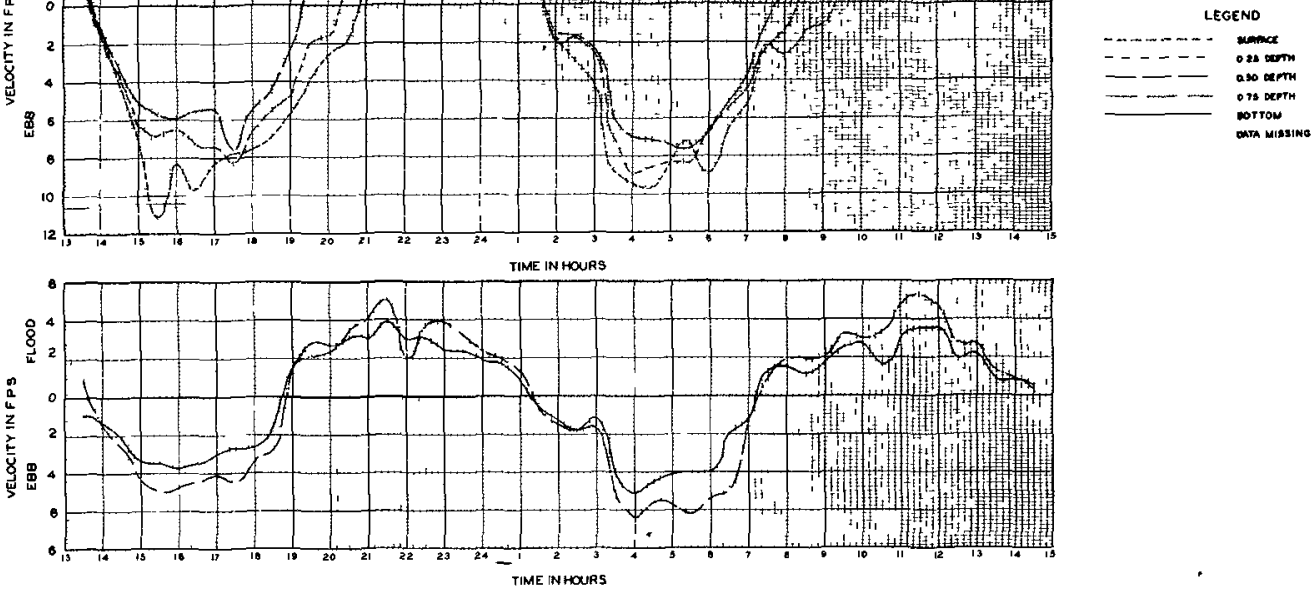

Fig. 14. Typical velocity - time - direction curve.

CROSS SECTION, RANGE
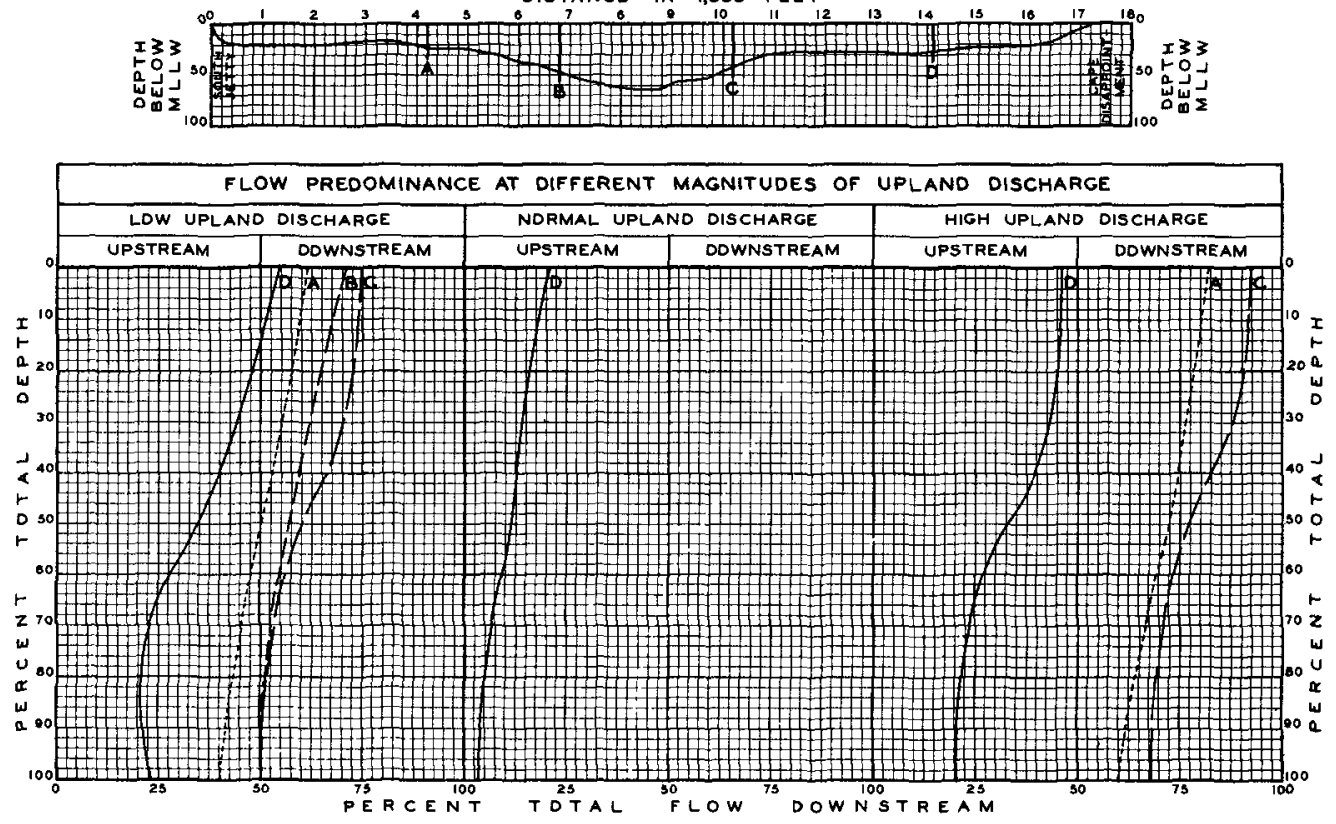

Fig. 15. Flow predominance - Range 1 . 


\section{COASTAL ENGINEERING}
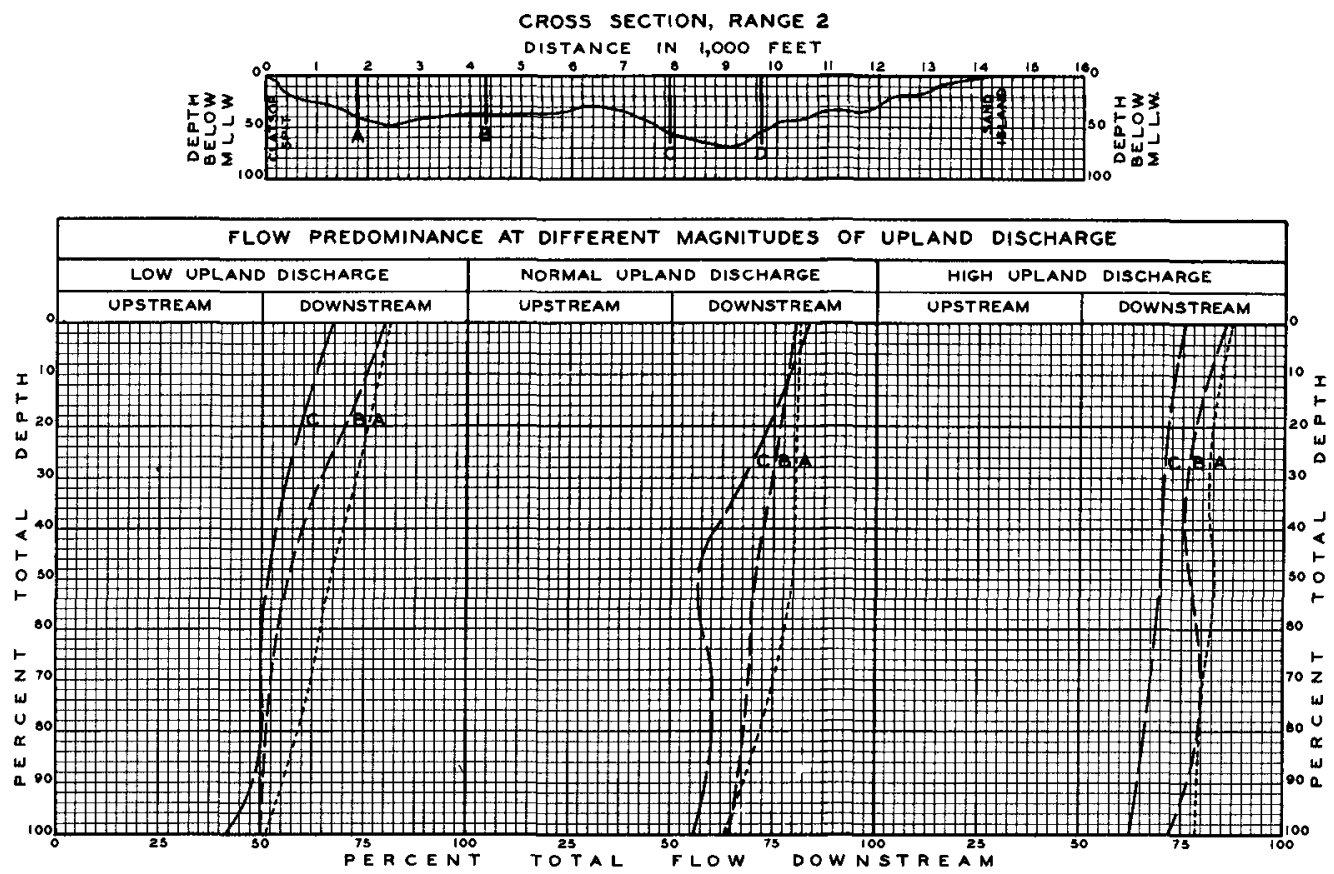

Fig. 16. Flow predominance - Range 2.

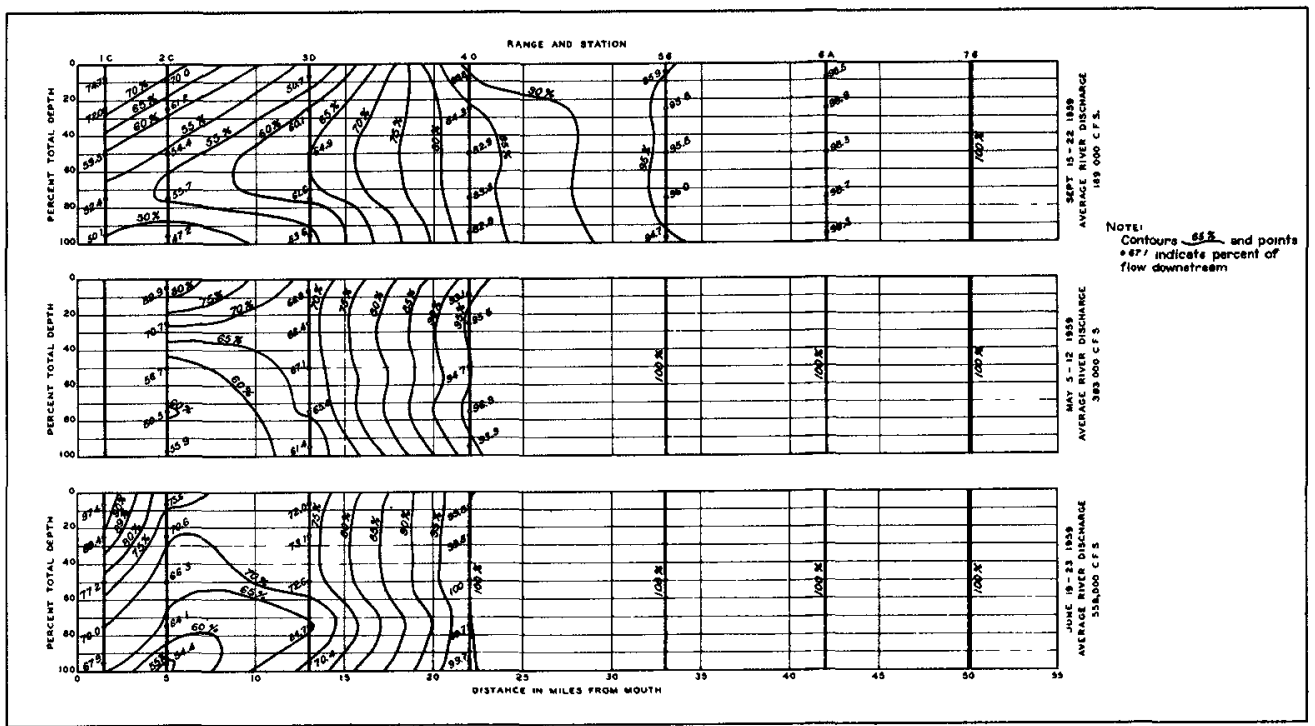

Fig. 17. Flow predominance profile - north ohannel. 


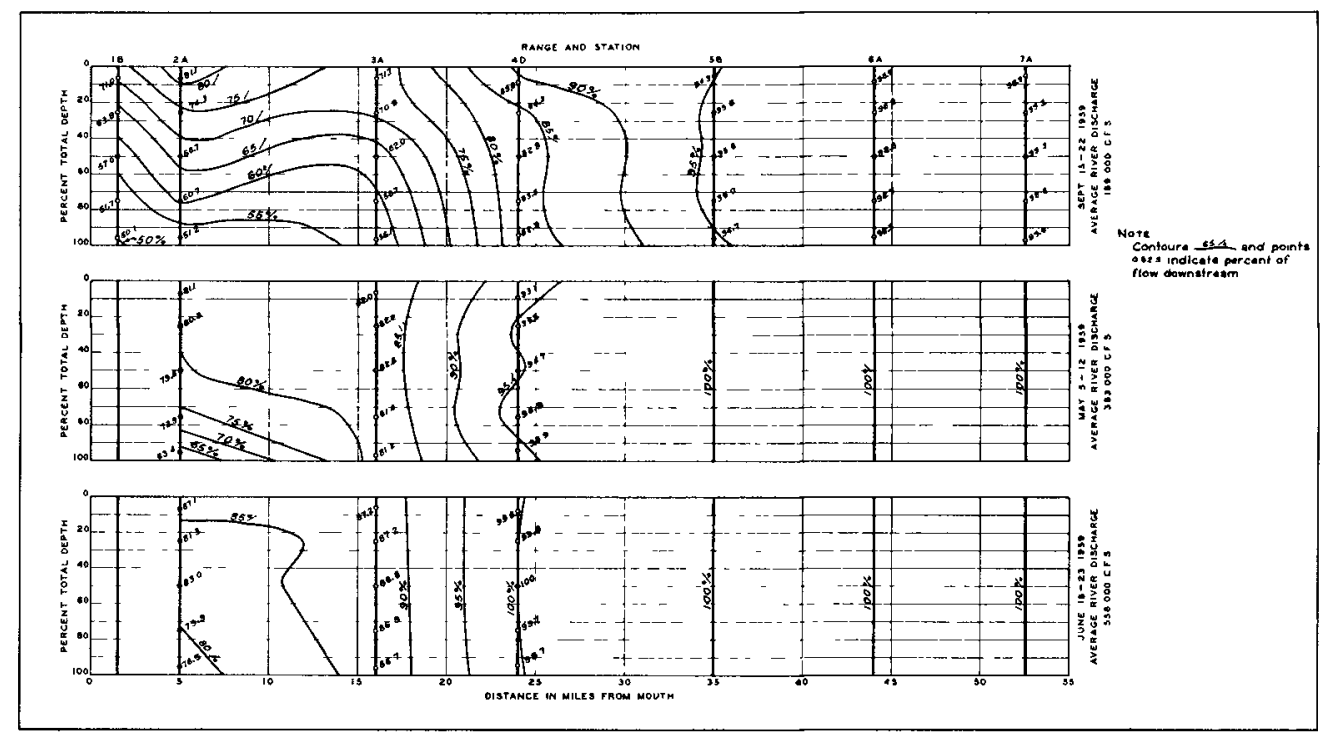

Fig. 18. Flow predominance profile - ship channel.
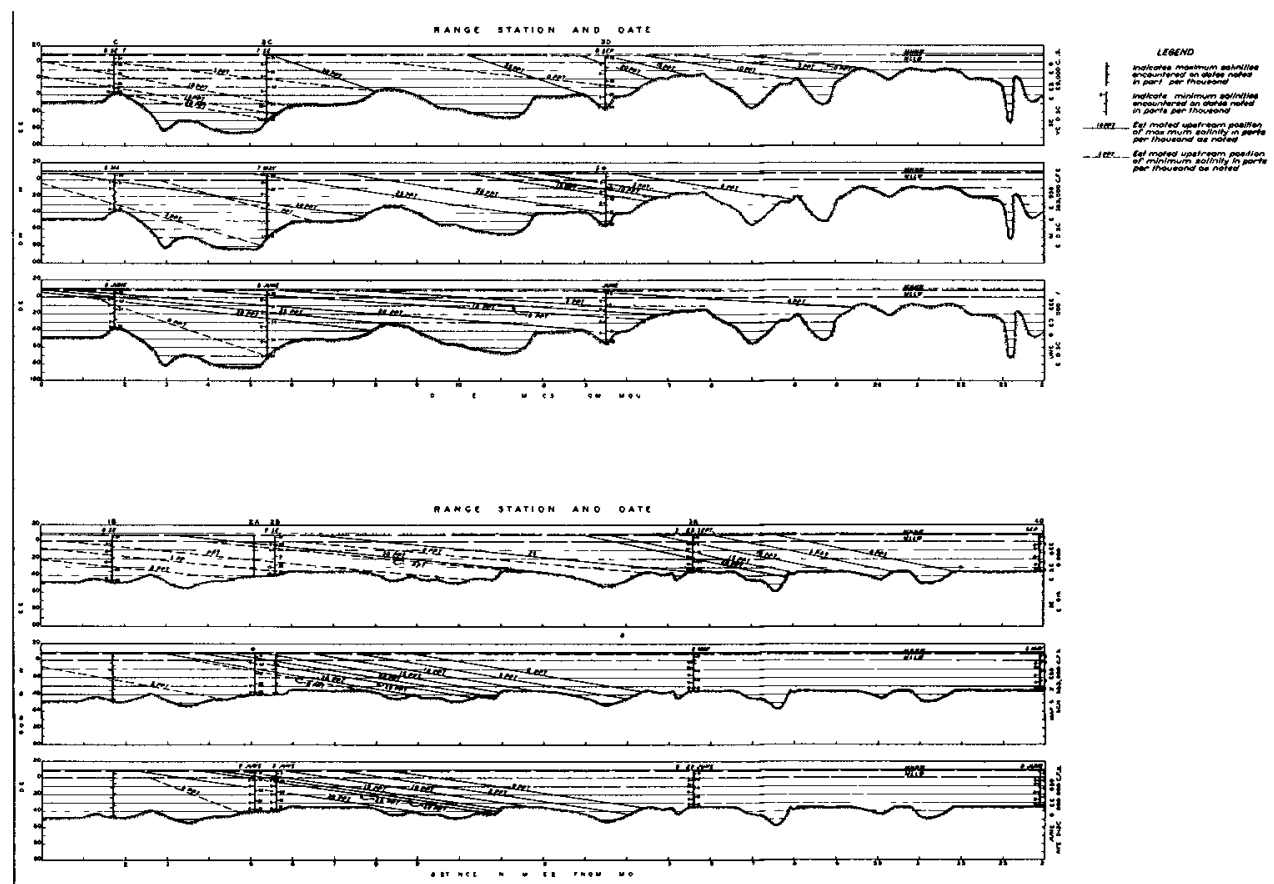

Fig. 19. Salinity profiles. 


\section{COASTAL ENGINEERING}

direction between flood and ebb and velocity were noted at each depth level throughout each observation cycle of approximately 25 hours' duration. From these plots it was possible, by computing the subtended areas above and below the zero velocity line, representing the volumes of flood and ebb flows, to determine the predominant direction of flow and the degree of predominance of such flows at those levels. Figure 15 shows changes in flow predominance noted at all stations and levels during each river discharge cycle of measurement on Range 1, and Figure 16 shows similar information obtained from observations taken on Range 2. From similar data developed along each measurement range it was possible to obtain flow predominance profiles along the northerly portion of the lower estuary, as shown in Figure 17, as well as along the adopted ship channel alignment shown in Figure 18.

Salinity Intrusion - Measurements of salinity, taken concurrently with those of velocity and direction, revealed significant intrusion by salinity within the lower 20 miles of the estuary, shown in Figure 19.

Temperature - Although a general trend of correlation between salinity and temperature was noted, this correlation was not conclusive due possibly to the time lag between the taking of the salinity and temperature observations.

\section{FINDINGS OF THE PROGRAM}

The prototype measurement program confirmed the view that the Columbia Estuary, like any other major estuary, is influenced by tidal forces to an extent governed by geography and the complex interaction of these forces with density, littoral, and perhaps other forces significant to the various problems experienced in the estuary. The program definitely identified the normal estuarine characteristic of upstream flow predominance along the bottom levels of the lower estuary in contrast to the downstream predominance noted in the upper levels. This revealed existence of a generally defined pattern of circulation within that region, which has governed the deposition of sediments forming the shoals obstructive to navigation. It has also given rise 


\section{PHENOMENA AFFECTING IMPROVEMENT OF THE LOWER COLUMBIA ESTUARY AND ENTRANCE}

to the view that the estuary now acts as a vast sediment trap, in which the phenomenon of density currents preclude, except during rare periods of extreme upland discharge, the movement of bottom sediments to the sea. In consideration of these findings, the comnittee on Tidal Hydraulics concluded that wille it would be possible to secure, by extensive and costly anzlytical analyses of observed data together with collection of adjitional data, an element of success in determining the cause or causes of the existing shoaling and other problems, such analyses could not accurately predict the effects of improvements works. Analyses of anticipated future problems would be even more difficult, if not impossible. Also, the effects of regulatory works that are completed, in progress, or planned for the Upper Columbia River and its tributaries, will be vary significant in the estuarine section of the river. In the light of all these conditions, the Committee felt that more must be learned regarding the physical factors governing the behavior of the waterway and that a comprehensive hydraulic model of the lower estuary reprasented the most important and urgently needed tool to aid in the development of this knowledge. Accordingly, the Committee recomnended that immediate steps be taken toward construction of a suitable hydraulic model of the Lower Columbia Estuary from $0 \exists k$ Point to the sea as the initial phase of a comprehensive model invastigation.

\section{OPFSHORE AND ESTJARINE SCOUR AND SHOAL}

\section{LONG-TERM TRENDS}

Concurrently with the analysis of observed data, studies were made of the general shoaling patterns since 1945 reflected by condition surveys made of the imnediate offshore area, the entrance area and two shoal areas upstream therefrom (Desdemona and Flavel shoals). These latter shoal areas are located in the vicinities of miles 8.8 and 10.7 , respectively. In reviewing these particular studies it should be recognized that they show only the changes occurring within the limits of the authorized channel and, consequently, such studies are not capable of showing the character or magnitude of changes oscurring elsewhere throughout the vast estuary and entrance area. Although these studies represent an analysis of known changes, they cannot, due to the limited area 


\section{COASTAL ENGINEERING}

covered, reveal more than an indication of the changes occurring in this vast area. A somewhat clearer indication of the shanges occurring in the lower estuary is revealed by a preliminary study of long-term scour and shoal trends made in 1961 which compared bank-to-bank hydrographic surveys of 1868 and 1958 within an ll-mile reach between north and south lines passing through upper Sand Island and Tongue Point. This study indicated that the total net shoaling occurring within this reach of the estuary, which did not include the tremendous clatsop Shoals, amounted to 77,000,000 Cubic Yards of material over the 90-year period. Deposition of this amount of material represents an average shoaling of about 3 feet over the 40 square miles of area considered. This preliminary study tends to confirm the view that the Columbia Estuary, since the days of initial improvement, has been acting as a vast sediment trap. Of this amount of shoaling, 66,000,000 Cubic Yards, or approximately 90\%, occurred in the lower 6-mile reach below Astoria which Includes the Desdemona and Flavel shoal areas.

\section{OFFSHORE}

A study of offshore conditions landward of the 16fathom depth line from 6 miles south to an equal distance north of the Columbia Entrance shows that great changes have occurred in this area since 1877. During the 50-year period, 1877 to 1926, which corresponds roughly to the period of jetty construction, this study revealed that there occurred a net accretion of 183,000,000 Cubic Yards of material north of the entrance and a net erosion of 374,000,000 Cubic Yards of material south of the entrance, as shown on Figure 20. This change is attributed in large part to the interception by the North Jetty of the predominately south-bound littoral drift which resulted in the accumulation of material north of the entrance and starvation of the offshore area immediately to the south. During the following 32-year period, 1926 to 1958, in which the influence of the jetties was continued, the study revealed that the incremental net accretion to the north of the entrance amounted to about 134,000,000 Cubic Yards while incremental erosion to the south amounted to about $130,000,000$ Cubic Yards as shown in Figure 21 . 
PHENOMENA AFFECTING IMPROVEMENT OF THE

LOWER COLUMBIA ESTUARY AND ENTRANCE

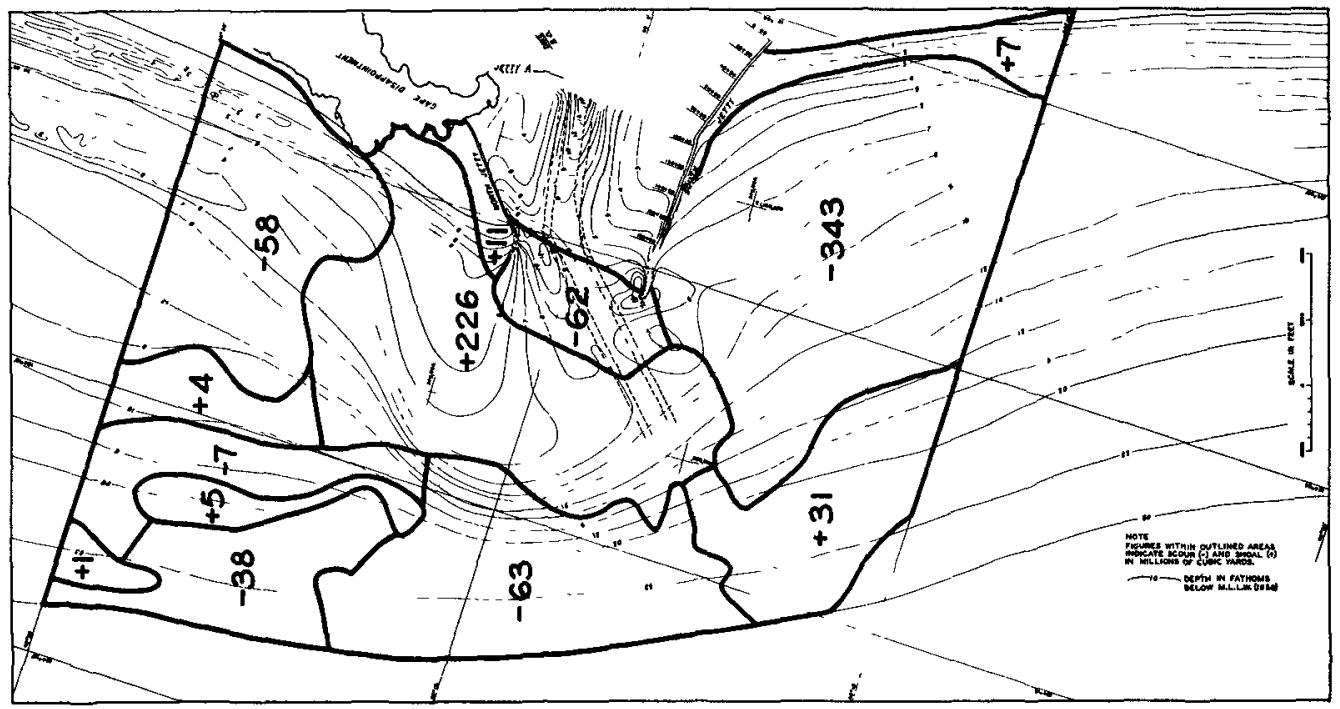

Fig. 20. Offshore scour and shor.l volumes, 1877-1926.

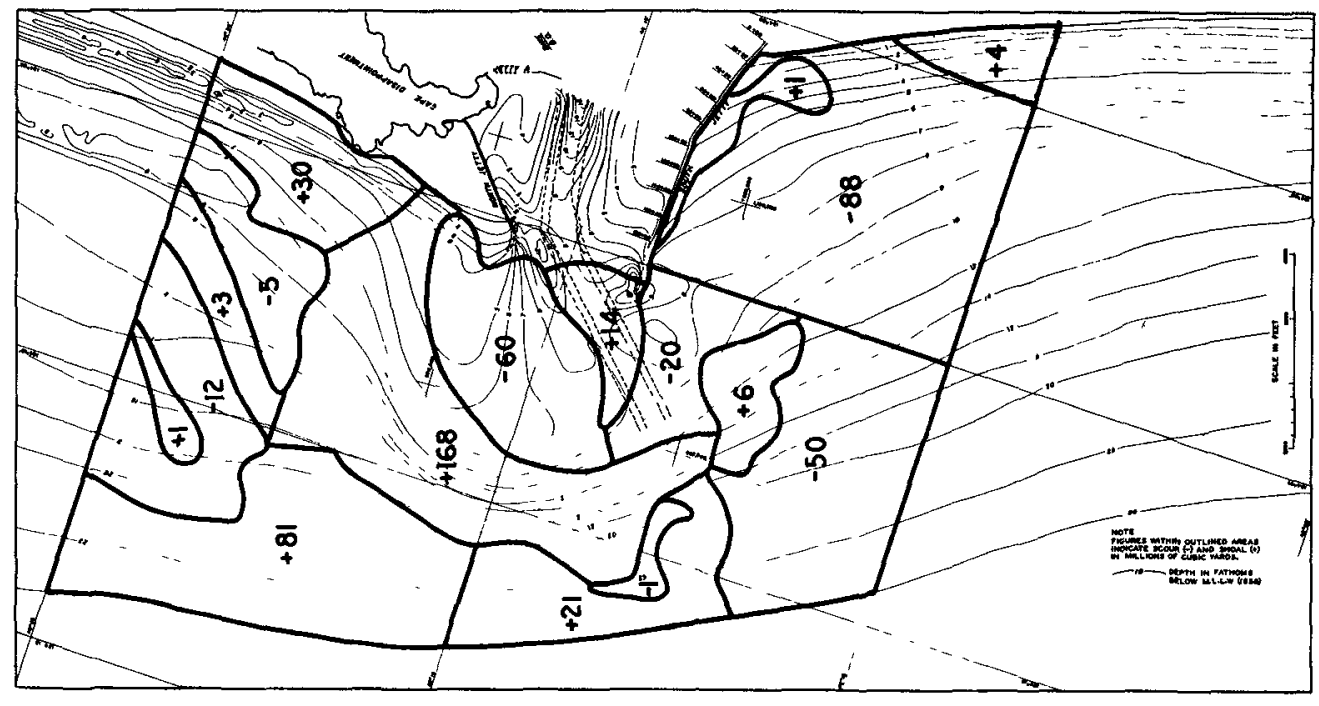

Fig. 21. Offshore scour and shoal volumes, 1926-1958. 
COASTAL ENGINEERING

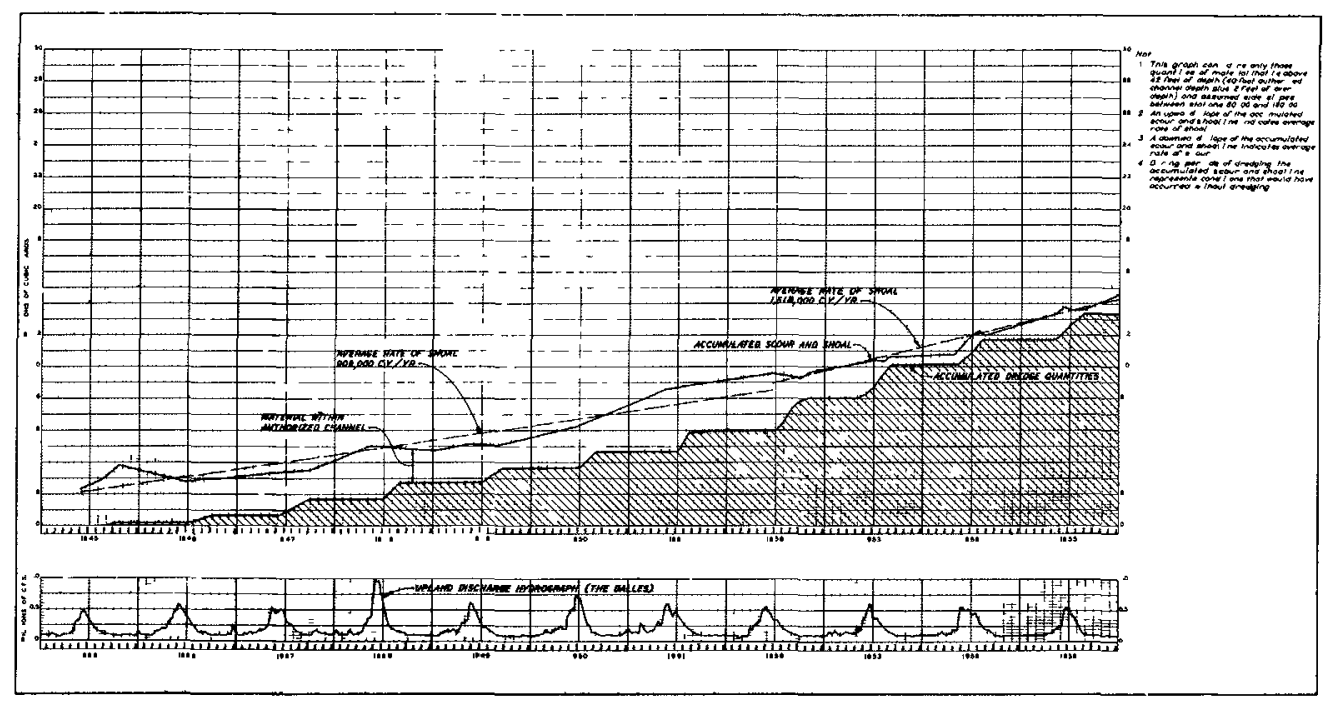

Fig. 22. Soour and shoal, 40-foot channel.

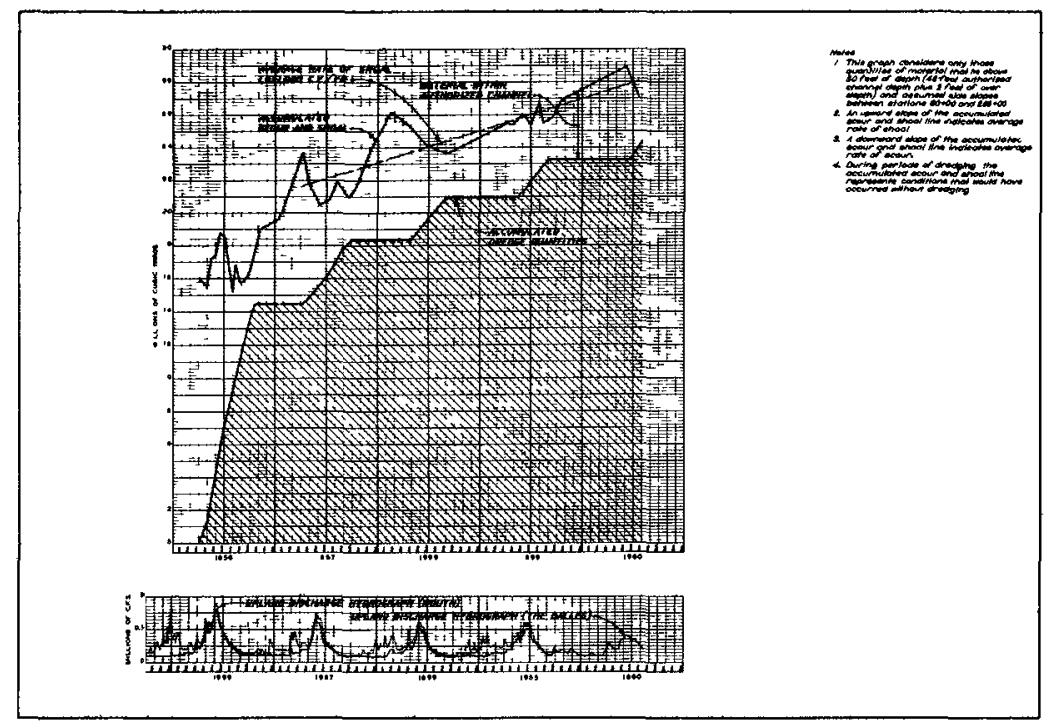

Fig. 23. Scour and shoal, 48-foot channel. 


\section{PHENOMENA AFFECTING IMPROVEMENT OF THE LOWER COLUMBIA ESTUARY AND ENTRANCE}

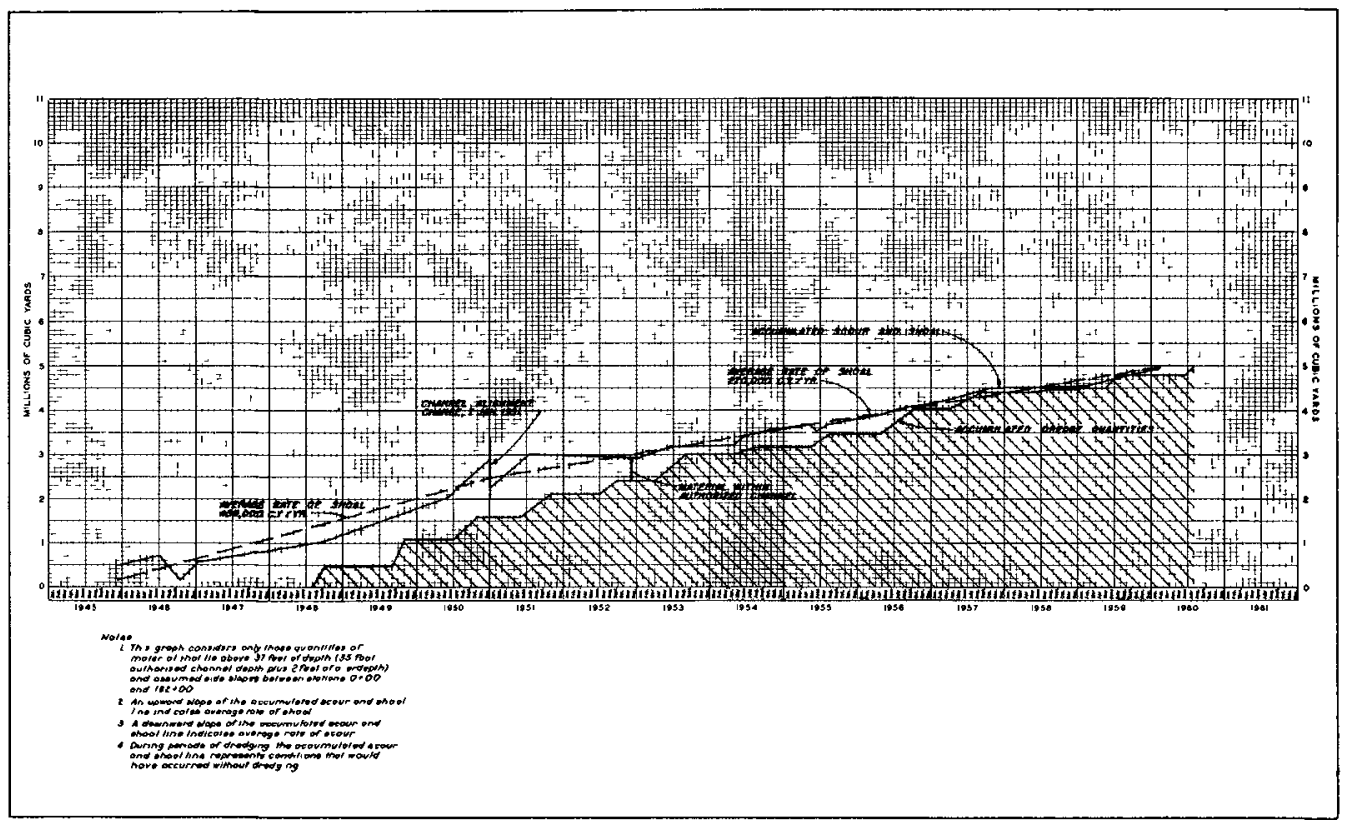

Fig. 24. Scour and shoal, Desdemona Shoal.

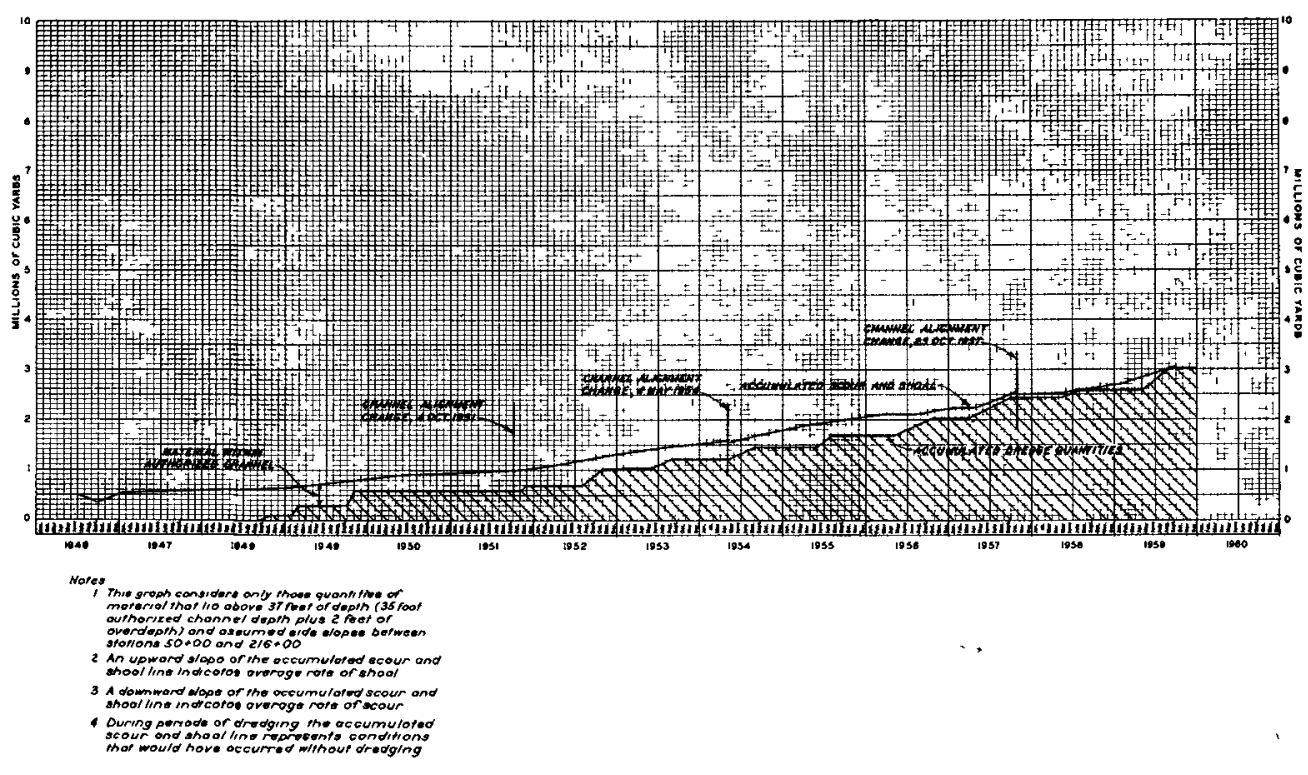

Fig. 25. Scour and shoal, Flavel Shoal. 


\section{COASTAL ENGINEERING}

ENTRANCE CHANNEL

Studies of changes occurring within the entrance channel since 1945 have revealed a trend for increased shoaling in this channel throughout this period notwithstanding the change in project depths from 40 to 48 feet effected in 1956 , and the associated increased dredging made necessary thereby. Figure 22 shows in graphical form accumulated dredge quantities, material remaining in the authorized entrance channel above 42 feet of depth, accumulated scour and shoal, and average rates of shoaling from 1945 to 1955, during which time the 40-foot project was being maintained. Figure 23 shows similar information for the period from 1956 to 1960, during which the 48-foot project was being developed. The average rates of shoaling within the entrance channel during these periods as shown on these graphs are as follows:

\section{$\underline{\text { PERIOD }}$}

$$
\begin{aligned}
& 1945-1952 \\
& 1953-1955 \\
& 1956-1960
\end{aligned}
$$

\section{AVERAGE RATE OF SHOALING, CY/YR}

$$
\begin{array}{r}
909,000 \\
1,518,000 \\
1,931,000
\end{array}
$$

DESDEMONA SHOAL

The results of similar studies of changes occurring within the authorized navigation channel, 35 feet deep and 500 feet wide, through Desdemona shoal during the period 1945 to 1960 are reflected on Figure 24. The average rate of shoaling prior to the change in channel alignment effected in January 1951 amounted to about 458,000 Cubic Yards a year. Since that time the shoaling rate has been reduced to an average of about 270,000 Cubic Yards a year.

\section{FLAVEL SHOAL}

Figure 25 shows the results of studies made of changes occurring within the authorized navigation channel through Flavel shoal since 1946. The average shoaling rate in this area during this period has been about 270,000 Cubic Yards a year. 


\section{PHENOMENA AFFECTING IMPROVEMENT OF THE LOWER COLUMBIA ESTUARY AND ENTRANCE}

\section{ATTRITION SOUTH OF SOUTH JETTY}

As previously mentioned, serlous attrition has been taking place in adjacent offshore areas along the oregon coastline immediately south of the south Jetty since the days of initial improvement. Perhaps the most startling visual evidence of this change is the gradual erosion during the last 25 years of the massive sand dunes which protected the arm of land connecting the mid-point of the South Jetty as completed in 1895 with Polnt Adams. These dunes have been breached along several hundred feet of shore immed1ately south of the structure and are quite thin for some distance farther south. The driftwood line indicates that the remaining beach berm has been overtopped during recent storms and it now appears that a complete breach to the lagoon in rear of the shore may occur at any time and is inevitable within a few years unless action is taken to prevent such a catastrophe. The low, permeable enrockment along the remains of the trestle at the root of the jetty separates the lagoon from the estuary proper, as shown in Figure 26, but the tide ebbs and flows freely through this structure. Because of the lag in tidal time between this part of the estuary and the open sea, about 40 minutes, a substantial head would develop along this light enrockment in the event of a breach between the sea and the lagoon. It is quite probable that failure of the structure by scour would be rapid in that eventuality and the breach would quickly develop into the primary course of the river outlet. A program of study and survelllance of offshore conditions in the vicinity of the South Jetty has been launched in an effort to determine the cause or causes of this problem with the view to undertaking appropriate corrective action. In the meantime, a temporary structural strengthening of the threatened area has been made to prevent a relocation of the entrance channel, pending completion of the study and survelllance program and analysis of the problem in the hydraulic model hereinafter described in detail.

\section{STATISTICAL WAVE STUDIES}

In continuation of Corps of Englneers' studies of characteristics of waves off the California coast, a 


\section{COASTAL ENGINEERING}

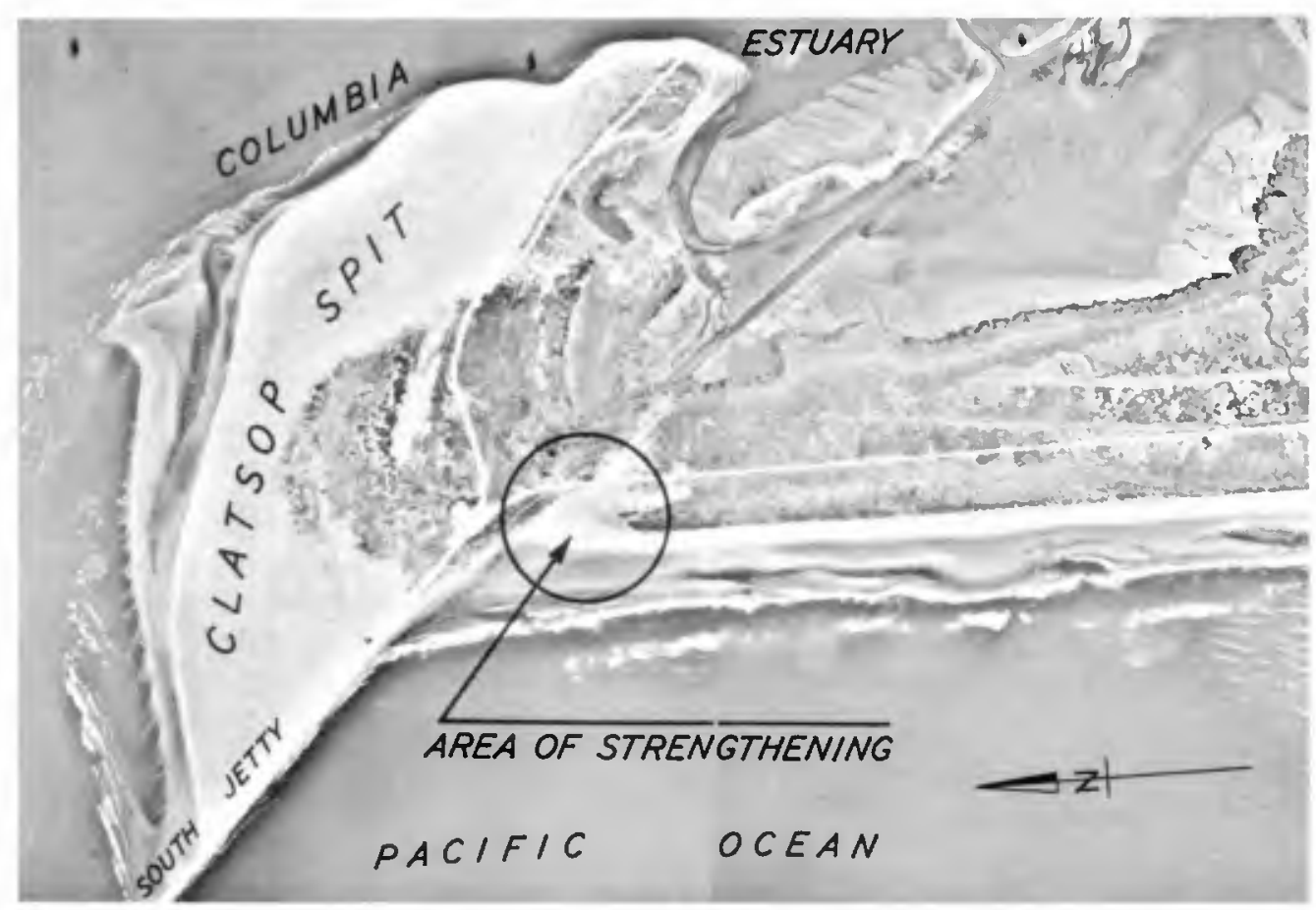

Fig. 26. Erosion south of south jetty.

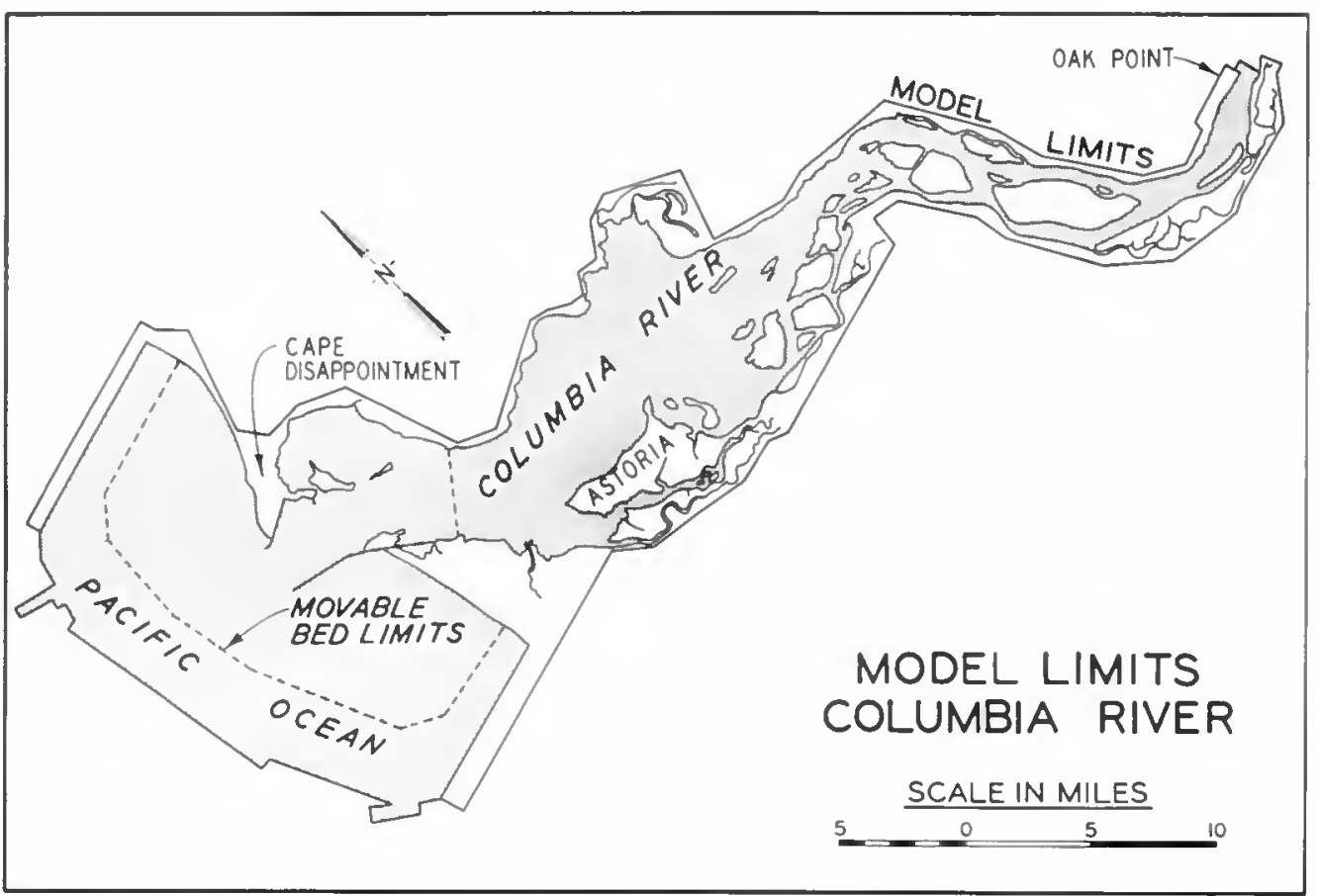

Fig. 27. General layout of Columia hydraulio model. 


\section{PHENOMENA AFFECTING IMPROVEMENT OF THE LOWER COLUMBIA ESTUARY AND ENTRANCE}

contract was awarded in August 1950 to the National Marine Consultants, Inc., Santa Barbara, California, for accomplishment of studies leading to the devalopnent of characteristics of waves prevailing off the coasts of oregon and Washington. These particular studies had as their objectives: (1) the development of wave statistics for three deep-water stations off the Oregon and Washington coasts based on conditions prevailing in 1956, 1957, and 1958; (2) statistics for 12 most severe storms at these selected stations during the period from 1950 to 1960; and (3) structural design wave analyses and wave modification analyses of conditions prevailing at and near the Columbia Entrance during the period 1940-1960. The results of these studies, discussed in the following paragraphs, are contained in manuscript reports 7 prepared by National Marine Consultants, Inc.

HINDCAST STUDIES, 1956, 1957, and 1958

The general area covered by these studies embraced the entire Pacific coast of Oregon and Washington as represented by three selected deep-water stations, one located off the entrance to Yaquina Bay, one off the Columbia Entrance, and one off the soast between Grays Harbor and the strait of Juan De Fuca. On the basis of 6-hour U. S. Weather Bureau synoptic charts covering extratropical cyclones and the Pacific high cell, these studies routed the paths and decay of meteorological disturbances to develop the height, direction, and period of the resulting wave conditions at the deep-water stations. The extratropical cyclones considered in these studies included storms moving into the Gulf of Alaska, storms moving directly into the study area, storms moving onto the california coast, and western Pacific storms. In addition to development of the characteristics of waves resulting from these meteorological conditions termed "Swell", the studies also determined similar characteristics for waves caused by local wind conditions termed "Sea". This latter condition often constituted a separate source of swell at an adjacent station, inasmuch as a wave in the form of sea at one station would show up as Swell at an adjacent station not under the influence of the same wind condition. It was frequently found during the course of the studies that as nany as six separate wave trains would sometimes occur simultaneously 


\section{COASTAL ENGINEERING}

at the deep-water stations. As a consequence, in the annual summary shown in Table I, the time over which "Swell" conditions oscur is greater than the elapsed time over the period covered. This tabulation and Table II show the significant wave height and direction frequency of waves caused by swell and sea, respectively, at the deep-water station off the Columbia Entrance, located at latitude $46^{\circ}-12^{\prime}$ North and longitude $124^{\circ}-30^{\prime}$ West:

TABIEE I - SWELI

AVERAGE ANNUAL HEIGHT - DIRECTION $1 /$ FREQUENCY DISTRIBUTION (PERCENT) $2 /$

AVERAGE TOTAL HOJRS - 10,508.45

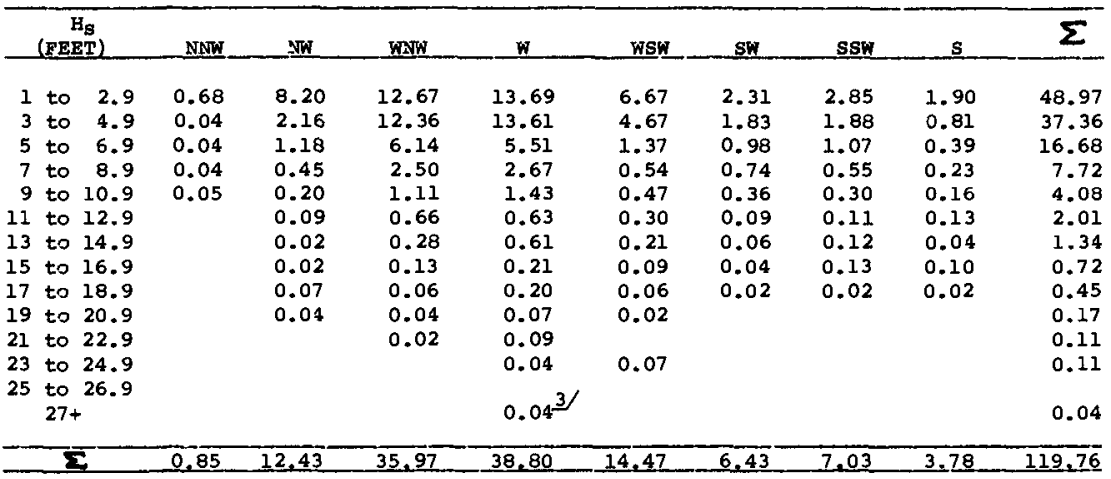

$1 /$ Direction fron which waves approich the deep-water station

$2 /$ Based on $365-1 / 3$ days

30 feet (March 1956)

TABLE II - SEA

AVERAGE ANNUAL HEIGHT - DIRECTION FREQUENCY DISTRIBUTION (PERCENT)

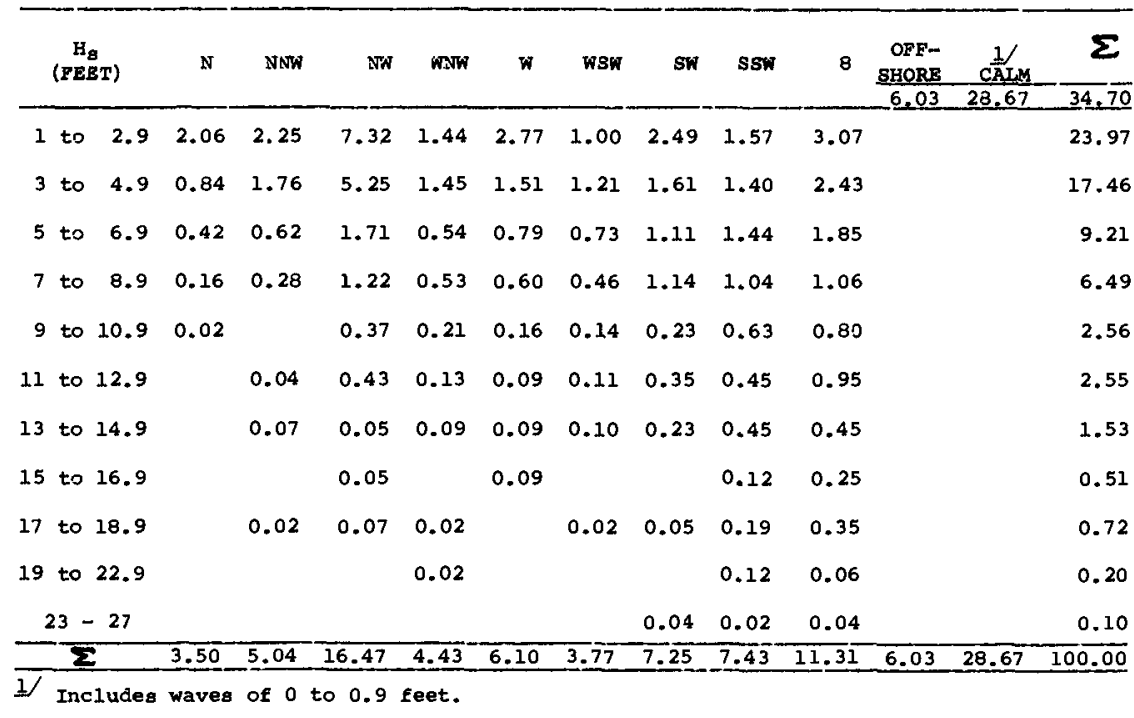




\section{PHENOMENA AFFECTING IMPROVEMENT OF THE LOWER COLUMBIA ESTUARY AND ENTRANCE}

SEVERE STORM WAVE CHARACTERISTICS, 1950 - 1960

Generally, extratropical cyclones giving rise to severe wind and wave conditions along the oregon-Washington coast originate near Japan and move eastward across the Pacific towards the Gulf of Alaska. The degree to wintch these disturbances affect conditions off the Columbia Entrance depends not only upon the intensity of the storm but also on the disposition of the Pacific high cell. During the summer months this cell is sufficiently removed to the north so that only a few storms approach the Oregon-Washington coast and those that do are relatively weak. During the period from October to May, however, with the southward shift of the Pacific cell, intense storms approach the coast. These storms develop in the form of rapidly moving intense frontal systems on low pressure centers and occur several times each winter. Although pre-frontal southerly winds often attain velocities of over 100 miles per hour in gusts along the coast, the winds associated with these storms seldom reach hurricane force over much of the area. However, the extent of storms in terms of duration and fetch can produce hurricane magnitude waves that last for relatively long periods of time. Principal wind fields associated with these storms produce south to southeasterly winds preceding a warm front, southwest to west southwest winds in the warm sector, and west southwest to northwest winds behind a cold front. Each of these wind regimes can develop high waves but offshore topography and coastal promontories dictate shallow water effects at coastal locations. Hindcast methods reveal the following characteristics of severe storm waves in deep water off the Columbia Entrance during the period 1950 to 1960 :

\section{DATE}

27 October 1950

21 January 1951

2 February 1951

18-19 December 1951

6-7 December 1952

5 December 1953

12-13 February 1954

19 November 1954

15 January 1956

\begin{tabular}{|c|c|c|}
\hline $\begin{array}{l}\text { SIGNIF ICANT } \\
\text { HEIGHT, FT. }\end{array}$ & $\begin{array}{l}\text { SIGNIF ICANT } \\
\text { PERIOD, SEC. }\end{array}$ & $\begin{array}{l}\text { DIRECTION } \\
\text { FROM }\end{array}$ \\
\hline 24 & II & SW \\
\hline 27 & 14 & WSW \\
\hline 25 & 13 & WSW \\
\hline 23 & 12 & NW \\
\hline 25 & 11 & sw \\
\hline 24 & 14 & WSW \\
\hline 30 & 13 & SSW \\
\hline 23 & 12 & SW \\
\hline 24 & 12 & SW \\
\hline
\end{tabular}




\section{COASTAL ENGINEERING}

\begin{tabular}{|c|c|c|c|}
\hline DATE & $\begin{array}{l}\text { SIGNIF ICANT } \\
\text { HEIGHT, FT. }\end{array}$ & $\begin{array}{l}\text { SIGNIF ICANT } \\
\text { PERIOD, SEC. }\end{array}$ & $\begin{array}{c}\text { DIRECTION } \\
\text { FROM } \\
\end{array}$ \\
\hline 3 March 1956 & 30 & 12 & $\bar{W}$ \\
\hline 26 December 1957 & 23 & 13 & W \\
\hline 23 January 1958 & 26 & 11 & SSW \\
\hline 11 December 1959 & 25 & 13 & SW \\
\hline
\end{tabular}

STRUCTURAI CRITERIA - COLUMBIA ENTRANCE

This study was composed of two parts, one part considered the characteristics of storm waves as applied to the design of structures at the Columbia Entrance and the other part related to refraction patterns assumed by waves from different directions and of different periods as they approach a 20-mile sector of the coast centered on the Columbia Entrance. The structural design wave analyses were based on hindcast studies of a number of severe storms which approached the entrance during the last 20 years. Considering the deep-water characteristics of waves generated by the previously-mentioned severe storms and the physical factors tending to modify these waves, such as exposure, refraction, shoaling, bottom friction and percolation, bottom slope and still-water depth at the entrance site, as well as the frequency distribution of wave heights, it was determined that structural criteria at the Columbia entrance should be based on the following general wave conditions:

$$
\begin{array}{llll}
\text { Significant wave Height } & \left(\mathrm{H}_{\mathrm{S}}\right) & 30.0^{+4} & \text { feet } \\
\text { Significant wave Period } & \left(\mathrm{Ts}_{\mathrm{S}}\right) & 13.0^{+1} \frac{1}{1} \text { seconds } \\
\text { Direction of Approach } & (\theta) & 235^{\circ}-15 \text { (from) }
\end{array}
$$

With a tide range of 8.5 feet, storm setup of 2.5 feet, and design depth of 51 feet, the most severe condition occurring within the period of study produced a wave with a significant height of 33.5 feet, significant period of 13 seconds, and an angle of approach of $234^{\circ}$ as shown in the following tabulation: 
PHENOMENA AFFECTING IMPROVEMENT OF THE LOWER COLUMBIA ESTUARY AND ENTRANCE

\begin{tabular}{|c|c|c|c|c|c|c|c|c|c|}
\hline & & & : & & & : & $\mathrm{DE}$ & IGN W & \\
\hline DE & PP WZ & [ER & : & MODIF: & CATION & $:$ & $\mathrm{AT}$ & ENTRA & CE \\
\hline $\begin{array}{c}\mathrm{H}_{\mathrm{s}} \\
\text { Feet }\end{array}$ & $\begin{array}{r}\mathbf{T}_{\mathbf{S}} \\
\text { Sec }\end{array}$ & $\begin{array}{c}\theta \\
\text { Dir. }\end{array}$ & $:$ & $\begin{array}{r}\text { Refraction } \\
\text { Coefficient } \\
\mathrm{K}_{\mathrm{r}} \\
\end{array}$ & $\begin{array}{c}\text { Shoaling } \\
\text { Coefficient } \\
\mathrm{K}_{\mathrm{S}}\end{array}$ & $\begin{array}{l}: \\
: \\
:\end{array}$ & $\begin{array}{l}\mathrm{H}_{\mathrm{S}} \\
\text { Feet }\end{array}$ & $\begin{array}{l}T_{S} \\
\text { Sec. }\end{array}$ & $\begin{array}{c}\theta \\
\text { Dir. }\end{array}$ \\
\hline 30 & 13 & $205^{\circ}$ & & 0.94 & 0.996 & & 28.0 & 13 & $200^{\circ}$ \\
\hline 25 & 13 & $225^{\circ}$ & & 1.11 & 0.996 & & 27.5 & 13 & $218^{\circ}$ \\
\hline 28 & 13 & $245^{\circ}$ & & 1.20 & 0.996 & & 33.5 & 13 & $234^{\circ}$ \\
\hline 30 & 13 & $270^{\circ}$ & & 0.97 & 0.996 & & 29.0 & 13 & $254^{\circ}$ \\
\hline 28 & 13 & $295^{\circ}$ & & 0.71 & 0.996 & & 20.0 & 13 & $263^{\circ}$ \\
\hline 23 & 12 & $315^{\circ}$ & & 1.24 & 0.996 & & 27.5 & 13 & $278^{\circ}$ \\
\hline
\end{tabular}

\section{RADIOACTIVE ANALYSIS OF BOTTOM SAMPLES}

In connection with the broad study being conducted by the Atomic Energy Commission of the distribution of Columbia River sediments as related to discharge of radioactive waste effluent from the Hanford complex, which is subsequently discussea, samples of bottom materials were obtained from five different points within the Columbia Entrance and from one location in the lower Estuary. In the Entrance area, one (Sample A) was obtained from the channel on Range 2, two (Samples $B$ and C) were obtained from each side of the entrance channel on Range 1, one (Sample D) In the entrance channel between the ends of the fetties, and one (Sample E) in the channel about 1 mile outside the jetties. In the lower estuary one sample (Sample F) was obtained from the channel near Harrington Point. These samples were analyzed by the General Electric Company in Hanford to ascertain the relative ages of isotopes present in an endeavor to determine the source of materials forming the samples. In these samples, the radio-isotope concentrations were extremely low in comparison with the natural radioactive content of the material. However, it was possible to make age estimates based on the $\mathrm{Zn}^{65}$ (245 day half-life) and $\mathrm{Cr}^{51}$ (26 day half-life) concentrations. A high $\mathrm{Cr}^{51}$ concentration relative to the $\mathrm{Zn}^{65}$ concentration would represent a "new" material whereas a low $\mathrm{Cr}^{51}$ concentration relative to $\mathrm{Zn} 65$ would represent much "older" material. The observed $\mathrm{Zn}^{65}$ and $\mathrm{Cr}^{51}$ concentrations in the above samples and their calculated ratio and relative ages were determined to be as follows: 
COASTAL ENGINEERING

\begin{tabular}{|c|c|c|c|c|c|c|}
\hline \multirow[b]{2}{*}{ Sample } & \multirow{2}{*}{$\begin{array}{l}: \\
: \\
:\end{array}$} & \multicolumn{2}{|c|}{$\begin{array}{c}\text { Concentration } \\
D / M / G r a m\end{array}$} & \multirow{2}{*}{$\begin{array}{l}: \\
: \text { Ratio }\end{array}$} & \multirow{2}{*}{$\begin{array}{r}: \\
\frac{\mathrm{Cr}^{51}:}{\mathrm{Zn} 65:}\end{array}$} & \multirow{2}{*}{ Relative } \\
\hline & & $\mathrm{Zn}^{65}$ & $: \mathrm{Cr}^{51}$ & & & \\
\hline $\bar{A}$ & & 17.1 & 11 & 0.6 & & $\overline{\text { New }}$ \\
\hline B & & 3.9 & 1 & 0.3 & & old \\
\hline C & & 5.8 & 5 & 0.85 & & New \\
\hline D & & 3.2 & 1 & 0.3 & & old \\
\hline $\mathbf{E}$ & & 6.3 & 5 & 0.75 & & New \\
\hline$F$ & & 7.6 & 30 & 3.95 & & Very New \\
\hline
\end{tabular}

The newer sediments suggest the likelihood that the material has been recently formed of particles moved into the estuary from upland areas while the older sediments very likely have moved into the entrance area from the ocean.

\section{DISTRIBUTION OF COLUMBIA RIVER SEDIMENTS}

The Atomic Energy Commission has launched a broad program of study and investigation aimed to (1) explore Columbia River sediments as they bear on the fate of radioisotopes released from the Hanford production complex and to (2) determine the interactions taking place in the columbia Estuary related to the ultimate distribution of sediments as measured by the concentration of radioactivity on these sediments. In this study, it is proposed to collect and analyze samples of bottom and suspended sediment to determine the principal chemical and physical exchange reactions involved, the sedimentation rates and accumulations, and the character of transport downstream of the sediments of sorbed or precipitated isotopes with the view to depicting in a quantitative manner the radioactive material balance in regard to its interactions with the sediments. In the estuarine section of the river the study is directed toward measurement of the physical forces of tides and currents and to sample the estuarine waters, biota, and sediments to determine: 


\section{PHENOMENA AFFECTING IMPROVEMENT OF THE LOWER COLUMBIA ESTUARY AND ENTRANCE}

a. The dispersion patterns and rates of interchange of the dissolved radioactivity in the fresh waters with those of the saline, brackish waters;

b. The removal of radioactivity from solution by means of chemical exchange with suspended and bottom sediments in the estuary; and

c. The rate and degree of removal of radioactivity from solution into the biological food web.

\section{STATUS OF INVESTIGATION}

It is not difficult to visualize that a study of this broad scope and complexity, considering its pioneering nature, will require several years to complete. Nevertheless, considerable progress has already been made along several broad phases of the investigation. Pursuant to contracts made with the Atomic Energy Comnission, the Department of Oceanography, University of Washington, has conducted field investigations to determine the characteristics of movement of Columbia River waters in the Pacific Ocean and has traced the freshwater plume of flow for many miles seaward. Other field investigations by that Department are directed at measurements of ocean salinity, chemical composition, transparency, temperature, density, plankton, and analysis of bottom sediments along the coast, across the continental shelf and into the abyssal plain of the ocean. In addition, studies by the Laboratory of Radiation Biology of that University of the radioactivity in biological organisms are under way. Through another contract, the U. S. Geological survey has activated a program to study fluvial sediment transport in the river as may be related to the sorption of radio-nucleides associated with such movement. Although this program will initially investigate sediment phenomena at a number of ranges across the Columbia River above Portland, it is possible that this program will be later extended to cover reaches of the river below that point. It is anticipated that the comprehensive hydraulic model of the lower Columbia Estuary and Entrance, subsequently described, will eventually be of much value in revealing the distribution of sediments in these regions. 


\section{COASTAL ENGINEERING}

RELATED STUDIES

The Department of Oceanography, Oregon State University, for a number of years has been engaged in the study of coastal and ocean phenomena prevailing along the coast of Oregon. In adition to its investigation of the nature of sediments in estuarine waters along this coast, the Department is engaged in preparing bathymetric charts of the offshore areas and plans shortly to map and study the physical features of the Astorla Canyon lying off the Columbia Entrance. Its study of the distribution of Columbla River water has revealed the seasonal offshore movements of ocean currents to the south during the summer and to the north during the winter. Offshore cruises have revealed large lenses of traceable river water upwards to 50 miles in diameter and 100 feet thick located hundreds of miles at sea. These lenses of water are somewhat warmer than the rivar water flowing from the Columbia Entrance.

COMPREHENSIVE HYDRAULIC MODEL INVESTIGATION

\section{AUTHORIZATION}

Pursuant to the previously-mentioned recommendations of the Committee on Tidal Hydraulics, which received the concurrence of the District Engineer, Portland, and Division Engineer, North Pacific Division, Portland, Oregon, the Chief of Engineers in March 1961 authorized the undertaking of a comprehensive hydraulic model investigation of the lower Columbia Estuary and Entrance. As the result, the U. S. Army Engineer Waterways Experiment Station in Vicksburg, Mississippi, has constructed and will shortly place into operation a hydraulic model winch will reproduce the lower 52 miles of the Columbia Estuary and a portion of the Pacific Ocean extending about eight miles north and south of the river entrance and offshore to the 20-fathom contour.

\section{DESIGN FEATURES}

The hydraulic model has been constructed to linear saale ratios, model to prototype, of 1:500 horizontally and 1:100 vertically. Tides and tidal currents are being reproduced by a primary tide generator located in the ocean portion of the model and a secondary tide generator losated 


\section{PHENOMENA AFFECTING IMPROVEMENT OF THE LOWER COLUMBIA ESTUARY AND ENTRANCE}

at the upstream limit of the model at Oak Point, Washington. The model ocean is equipped with wave generators to reproduce ocean wave effects on the movement and deposition of sediments, as well as a circulating system to reproduce the effects of alongshore littoral currents on sedimentation phenomena. The model will be operated with salt water, salinity scale $1: 1$, in the model ocean, and with fresh water supplied by the Columbia River and its significant tributaries, so that density effects on hydraulic and shoaling phenomena will be reproduced. The model will be of a combination fixed-bed and movable-bed type, so that critical portions of the model estuary and entrance can be converted from one type to another, thus employing the advantages of each type in conducting studies of the various problems involved. Figure 27 shows the general layout of the model as well as the limits of the fixed-bed and movable-bed portions.

\section{MODEL VERIFICATION}

Hydraulic and salinity verifications of the model were based on prototype measurements of tides, current velocities, current directions, and salinities observed during the 1959 prototype measurement program. The observation stations manned during that program, as well as the range of conditions covered, were specifically planned to provide the data needed for these phases of model verification. As the model is adjusted to reproduce simultaneously all pertinent phenomena observed at the prototype stations during the 1959 measurement program, pertinent phenomena at intermediate points in the prototype are also being reproduced to scale. Verification of bed movement in the movable-bed portion of the model involves an empirical process of adjusting the forces involved, the nature of the bed material, and the duration of model operation until the model will reproduce within sufficient accuracy the significant changes in bed conditions which have occurred in the prototype during known periods of time. These significant changes include the formation of shoals in the navigation channel, accretion and/or erosion in areas outside the navigation channel, and accretion or erosion attributable to structures constructed in the prototype during the period of time used for model verification purposes. Once the model has demonstrated its 
ability to reproduce all significant changes in bed conditions of the prototype, the actual model operation time required to effect such changes is used as a measure of the time scale for bed movement. Thus, if the model consistently shows that changes which occurred in the prototype between hydrographic surveys made at intervals of one year are being reproduced in the model during 20 hours of operation, then the time scale for bed movement would be 20 hours model to one year prototype, or about one to 438 . Although the time scale for bed movement in the Columbia model will not be known until the movable-bed verification is accomplished, the time scale for reproduction of hydraulic and salinity phenomena, derived mathematically from model linear scales, will be about one to 50. Thus the model, within the time scales thus determined, will reproduce tidal elevations and phases, current velocities from bank to bank and from surface to bottom, salinity concentrations and distribution throughout the saline portion of the estuary, and movements of sediments within the movable-bed portion of the model. In addition to reproducing these phenomena, the model will automatically reproduce the dilution, dispersion, and flushing patterns of any contaminants that might be introduced and readily mixed with the waters of the estuarine system.

\section{MODEL TESTING}

It is anticipated that during the next 25 years, continued growth and industrial development within the Columbia River basin, including construction and completion of many water development and conservation projects, will have a marked effect on the quality as well as characteristics of Columbia River flows. In order that the Columbia model may be a useful tool during this critical phase of development, the model has been constructed to have a useful life of at least 25 years. During the early portion of its life the model will serve to solve problems of present-day urgency, after which it will be available to lend guidance to the solution of future estuarine problems as they develop and affect the welfare of the lower Columbia Estuary and Entrance area. Having been successfully verified, tests now proposed for the model are outlined in the following paragraphs.

Entrance Relocation - The threat of a channel relocation through the shore end of the south Jetty resulting from the loss of shore material in that area poses an extremely difficult and challenging problem to those charged with maintenance 


\section{PHENOMENA AFFECTING IMPROVEMENT OF THE LOWER COLUMBIA ESTUARY AND ENTRANCE}

of a usable and satisfactory entrance channel for navigation. Considering the enormous build-up of materials imnediately offshore and north of the present entrance, the attrition of the shore and offshore areas imnediately south thereof, and the continuing growth of the clatsop spit shoals, it is not difficult to percelve that this threat is quite iminent, particularly winen the destruative effects of storms experienced at the Columila Entrance are direated toward such an eventuality. Recognizing the possibility that such a relocated entranice, if developed in accordance with aareful planning, could possess merit over the present entrance, insofar as channel maintenance is concerned, the nodel offers an opportulity for careful and complete engineering analyses of the problemis associated with the levelopment of such a new channel. In the model the factors now producing the large shoals in the present entrance can be evaluated as they would effect conditions along the relocated channel, and permit engineers to investigate all phases of the potential problem before it occurs, thus saving miah time, money and effort which might otherwise be expended. Considering the dislocation to established navigation wilch would occur by a sudden relocation of the entrance channel, one of the initial model tests will be to explore the consequences of such a relocation and to determine the courses of action to be taken.

Jetty Rehabilitation - As previously mentioned, jetties at the Columila Entrance have been rehabilitated on several occasions to restore portions of these structures which have been damaged or destroyed by destructive storms. Rehabilitation undertaken in the past has largely been directed toward restoration and increasing the helght and sections of those portions of the structures lying above mean sea level on the assumption that the portion below this level, if not in satisfactory condition, would make itself evident by complete failure of the jetty structure. This assumption has been proved correct as subsidence of the struatures, particularly after their inftial construction, revealed the fact that $a$ certain amount of consolidation was required to effect $a$ stable jetty foundation. Such a foundation has been secured over the years until now rehabilitation is confined to restoration of those portions of the structures damaged by wave action. Notwithstanding the limited nature of rehabilitation, the work involved is costly and must be conducted during the relativaly calm season of the year. Its cost and the construction difficulties involved, together with experience gained at other river entrances, have raised question among 
engineers as to the value of such limited rehabllitation insofar as maintenance of project depths are soncerned. Although completely rehabilitated jetties undoubtedly provide some benefit to small craft against heavy seas as long as these craft remain in the lee of these structures, these particular benefits are seldom of sufficient magnitude to justify the large rehabilitation costs involved. Further, if sea conditions beyond the jetty are such as to preclude safe operation of small craft, there is little reason to expect that the prudent operator of such a vessel would have need for any protection a rehabilitated jetty might provide. Despite the deteriorated condition of the South Jetty at the entrance to Grays Harbor, Washıngton, just north of the Columbia Entrance, depths in the authorized entrance channel to that harbor are more than twice those for whlch the jettles were designed to maintain. Although early rehabilitation of that jetty is now being consldered, this work is required to preserve its structural integrity against attack by currents which threaten to undermine the jetty foundation. Aside from work of such emergent nature, there appears to be sound basis for question as to the actual value of rehabilitation for the sole purpose of preserving the upper portions of jetties. Certainly area exists for exploration of the most economical time interval for conducting such rehabilitation operations, taking into consideration the construction problems involved and the actual benefits to be expected. The Columbia model, in its inltial testing phase, will provide an opportunity to demonstrate the value of recent rehabilitation work and such further work as may be proposed for the immediate future.

Entrance Channel Realignment - As may be noted from recent condition surveys, generally as shown on Figure 9, the authorized entrance channel takes a southwesterly course through the outer bar as it proceeds seaward through the Columbia jetties. Although dredging on the outer bar on this alignment is not now significant, heavy dredging is required to maintain the adopted channel through the Inner bar within the jetties. Just west of the authorized channel hydrographic surveys reveal a natural parallel channel of even greater depth which appears to offer a possibility of decreasing dredging requirements if, through some means, advantage might be taken of the greater depths afforded, without introducing an undesirable risk to navigation. In connection with model studies of different channel alignments at the 


\section{PHENOMENA AFFECTING IMPROVEMENT OF THE LOWER COLUMBIA ESTUARY AND ENTRANCE}

Southwest Pass entrance to the Mississippi River, it was found that the introduction of a degree of sinuosity into the channel alignment took advantage of the prevalling river and ocean forces to secure a more satısfactory eatrance channel. Such an expedient, in combination with realignment of the entrance channel, might have definite merit at the Columbia Entrance and will be tested in the comprehensive model.

Salinity Intrusio스 and Shoaling - The model will accurately define the extent of salinity intrusion in the columbia Estuary under the different conditions of tide and upland discharge and will show the part such intrusion plays in the development of the shoaling regime of the estuary and entrance. The movable-bed tests will show the meahanism responsible for the formation of clatsop spit, the forces involved in the great imbalance of offshore materials to the north and south of the present entrance, and the role wilch alongshore littoral forces play in the formation of these large shoal and attrition areas. Once these forces are slearly understood and their interrelationships evaluated in the model, tests san be made of structural measures designed to take advantage of these forces in the development of an entrance channel that will be easier and less costly to maintain.

Reduction of Entrance Width - Although early engineers were guided by observations of existing bank-to-bank widths in the estuary in determining the present width between the ends of the jetties, approximately two miles, it has long been felt $b_{y}$ the present-day engineers that these strustures were too far apart to efficiently guide the forces at work to produce an easily malntained entrance channel. In the model it will be possible to test the value of more confining struatures, such as would result from extension of the alignment of the original south Jetty past the "knurkle". Other confining works, such as groins constructed perpendicular to the South Jetty, could also be tested and evaluated.

Jetty "B"- - One of the early tests in the model will evaluate the merit of Jetty " $B$ " as presently authorized oy the 48-foot entrance project. The 1959 prototype neasurament program revealed the existence of generally. upstrean currents at all times along the bottom of the "cul-de-sac" in which Jetty "B" would be located. Such a structure could possibly tend to cause undermining of the existing North Jetty through 
reflection of the prevaliing bottom upstream currents toward that structure. The merits as well as the possible adverse effects of Jetty "B" will be explored fully in the model.

Other Tests - The above brief discussion outlines some of the aarly tests proposed for the comprehensiva columbia Estuary and Entrance model. Doubtlessly, numerous other tests will be made as new problems arise through increased growth and development of the Colunbia Basin. Not the least of these will be that caused by increased pollution of Columbia River waters through domestic and industrial waste disposal. It may be expected that the Columbia model, like models of estuaries elsewhere, particularly along the heavily developed Eastern Seaboard, will define the flushing pattern peculiar to the Columbia Estuary and will point the way to solution of this problem as well as other problems not now envisioned by engineers of this day.

\section{SUMMARY OF PRESENT KNOWLEDGE}

The vastness of the lower Columbia Estuary and Entrance area is only one characteristic that belies the complexity of the problem of achieving and maintaining a reasonable degree of permanence insofar as navigation is concerned. The problen is further complicated by the dynamic forces of ocean salinity, littoral drift, river flow, and storm waves which are primarily responsible for the geographical formation of the area and the interactions taking place therein. These characteristics, together with the extremely large and variable range of diurnal tidal action prevailing along the oregon and Washington coasts, give to the Columbia Estuary and Entrance a unlqueness beyond compare. The tremendous amounts of energy expended by these out-sized forces in the entrance and estuary area exceed those expended in any similarly improved area anywhere in the world today. Past efforts to regulate these forces in the interest of navigation have led to construction of massive and long, stone training structures, the North and South Jetties, which confine the ship channel to a relatively limited area but do not assure adequate depths for navigation without continual dredging year after year. Comparison of depths shown by hyarographic surveys undertaken since the beginning of improvement reveal that the estuary is gradually becoming shallower, being fillec with bottom materials carried by the river and transported from adjacent ocean areas. Clatsop spit shoals, which 


\section{PHENOMENA AFFECTING IMPROVEMENT OF THE LOWER COLUMBIA ESTUARY AND ENTRANCE}

continually encroach on the present entrance channel, constitute the most striking evidence of this process. Other evidence, although less spectacular, such as the changes occurring immediately upstream from these shoals, confirm this trend. Measurenents of current direction and velocity, as well as salinity and temperature, at different depth levels throughout the estuary reveal the existence of a salinity block or salt-water wedge action along the bottom through the entrance, which not only prevents the movament of bottom materials to the sea but encourages the movement of ocean materials into the estuary. This intrusion of salinity into the estuary, an incidental by-product of improvement, now controls the regimen of the estuary area. Another incidental effect of improvement, interception of the predominately north to south alongshore littoral drift by the North Jetty, has created a severe imbalance of materials imnediately offshore the entrance. This imbalance threatens not only to pinch off the present entrance channel by the accumulation of littoral material from the north but, with the assistance of storm waves, also threatens to produce a major relocation of the river outlet to the south, where attrition of the shore and offshore area has weakened the confining influence of the South Jetty. The comprehensive hydraulic model of the Columbia Estuary and Entrance, now undergoing verification tests at the Waterways Experiment station, offers the sole means of developing an engineering analysis and evaluation of the forces responsible for the pending cataclysm in this area and of determining the action which might be taken to prevent such an eventuality.

\section{CONSIDERATIONS FOR THE FUTURE}

Achievenent of all feasible storage in the Columbia River headwater areas in the primary interests of flood control, hydroelectric power and irrigation will alter materially the pattern of river flows in the lower estuary. As shown on Figure 28, these flows have in the past ranged from a minimum of 59,000 cfs to a maximum of about 1,300,000 afs. Regulation by such storage will reduce the future range of these flows by lowering extreme discharges to not more than 600,000 afs and by increasing minimun flows to zbout $150,000 \mathrm{cfs}$. This alteration of the river flow pattern may be expected to eliminate any possible flushing of bottom sediments from the estuary to the sea by extreme river discharges of the magnitude that has been experienced in the past. On the other hand 


\section{COASTAL ENGINEERING}

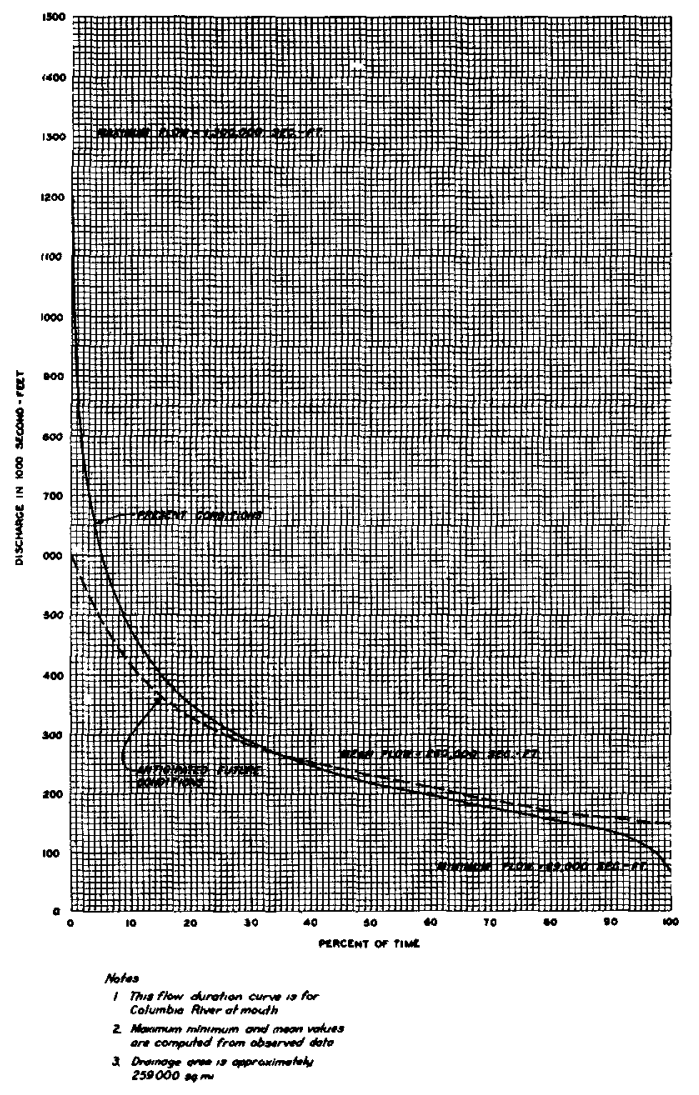

Fig. 28. Flow-duration curre.

the increase in low river flows may, to a small degree, reduce the extent of salinity intrusion in limited portions of the lower estuary. While this regulation of river flow is not expected to appreciably modify the total amount of fresh water entering the estuary, it will, by reduction of extremely high discharges, tend to maintain the permanency and quite likely increase the degree of salinity intrusion into the estuary. Also, as revealed by experience gained at the Savannah Estuary, such regulation of upland flows may tend to concentrate shoaling to a much more limited length of the Columbia Estuary.

History of the Pacific Northwest reveals that channels of greater and greater depth are required to support the increase in ocean commerce attending the continued growth and economic development of this region. Due to the geography of the entrance area and the severe wave and weather conditions which prevail in that area during the winter months, depths of 48 feet are necessary for safe passage 


\section{PHENOMENA AFFECTING IMPROVEMENT OF THE LOWER COLUMBIA ESTUARY AND ENTRANCE}

through the Columbia Entrance, while the main Columbia channel inland now provides only a depth of 35 feet. Recent increases in the size and draft of the world fleet of ocean carriers have revealed a need for increasing the minimum depth of the main river channel above the entrance to Portland and Vancouver from 35 to 40 feet, and plans to effect such further deepening of the main channel are now under way. Although no corresponding deepening of the entrance channel is planned at present, due to the fact that elimination of delays caused by the 48-foot entrance channel to prospective traffic will not now justify such further deepening, it is obvious that eventually, as the region continues to grow, greater entrance depths will be required. Provision of the contemplated 40-foot channel in the river above the entrance is expected to extend the effect of salinity intrusion farther into the estuary, causing changes in shoaling patterns and increased dredging to maintain the larger channel dimensions. Any further deepening of the present entrance channel will intensify saline conditions within the estuary and certainly modify, and quite likely aggravate, the shoaling problem.

As previously mentioned, pollution of estuarine waters is not now a serious problem facing those charged with maintaining the quality of Columbia River water. However, with the expected growth in population and industrial development in the area tributary to this great river, experience elsewhere, particularly along the Atlantic Seaboard, points to the eventual need for strict control of pollutants disposed in the Columbia River. The extent of such control will largely be governed by the flushing characteristics of the Columbia Estuary as affected by improvements designed primarily for the sole benefit of navigation. It does not appear unreasonable that the degree of pollution induced into the river may some day exceed the flushing capacity of the estuary.

All these problems are susceptible to study, analysis and evaluation in the comprehensive hydraulic model of the lower Columbia Estuary and Entrance and there is little doubt that the model will contribute greatly to the solution of these and other problems of an unforeseeable nature at this time. In the event the model demonstrates the merit of a planned major relocation of the entrance channel through the South Jetty, it appears probable that many of the problems created by salinity intrusion into the estuary may also be solved or greatly alleviated. Such a planned relocation 
would involve construction of a navigation canal in the Point Adams area of the dimensions required by ocean commerce connecting the estuary at that point with the deep ocean area just south of the present South Jetty. A lock might be required in this canal at Point Adams to eliminate or reduce the intrusion of salinity into the estuary from the canal. Also, a new but substantially shorter South Jetty may be required to firmly fix the entrance channel between this new structure and the enrockment forming the present South Jetty. With such a relocated entrance channel and salt-water 1ock, the present entrance would be abandoned, closed to navigation, and allowed to shoal naturally. If shoaling in the present entrance channel reduces controlling depths to the equivalent of those prevailing prior to 1885, it may be expected that the intrusion of salinity into the estuary will be correspondingly reduced untll it is no longer a controllins factor in the estuarine regime. With the reduction of depths created by shoaling it may be expected that, even with the minimum regulated flow of about 150,000 cfs, river flows will completely usurp the entire channel section at all times and there will no longer prevall the marked density currents which are now so sharacterlstic of the intrusion of salinity into the estuary. At that time, except for the modification of the river flow pattern resulting from upstream storage, the restored flushing characteristics of the river would move the bottom sediments to the sea in a manner similar to that which prevailed prior to man's attempt to improve the entrance. The fresh-water estuary thus obtained will be capable of more complete flushing of pollutants and it is reasonable to expect that dredging requirements for navigation will be considerabl: less demanding. Along with such achievement there would be restored the uninterrupted predominately north to south littoral drift past the present entrance which would nourish and restore the starved shoreline immediately to the south. Although restoration of the natural littoral regime may eventually require dredging of the relocated entrance channel this work will not be required for many years due to the depths now existing in that area. Thus, with restoration of conditions which largely prevalled prior to improvement, the strategic value of the Columbia Estuary and Entrance area may be assured throughout the foreseeable future at reasonable costs. 


\section{PHENOMENA AFFECTING IMPROVEMENT OF THE LOWER COLUMBIA ESTUARY AND ENTRANCE}

\section{ACKNOWLEDGMENT}

The discussion and data presented herein were obtained from research conducted under the Engineer Planning Program of the United States Army Corps of Engineers. The permission granted by the Chief of Engineers to publish this information is appreciated.

\section{REFERENCES}

1. Report of the Board of Engineers, dated 13 October 1882, printed as part of Senate Executive Document No. 13, 47 th Congress, 2d Session.

2. Report of the Board of Engineers, dated 24 January 1903, printed as part of Appendix XX of Annual Report, Chief of Engineers, U. S. Army, 1903, Part 3, Volume 3.

3. Mouth of Columbia River Current Survey, 1932, on file in the Office of the District Engineer, U. S. Army Engineer District, Portland, Oregon.

4. Simnons, H. B. and Schultz, E. A., "Fresh Water Salt Water Density Currents, a Major Cause of Siltation in Estuaries," Technical Bulletin No. 2, April 1957, Committee on Tidal Hydraulics, Corps of Engineers.

5. Ippen, Arthur T. and Harleman, Donald R. F., "OneDimensional Analysis of salinity Intrusion in Estuaries," Technical Bulletin No. 5, June 1961, Committee on Tidal Hydraulics, Corps of Engineers.

6. Report of the District Engineer, U. S. Army Engineer District, Portland, "Interim Report on 1959 Current Measurement Program, Columbia River at Mouth, oregon and Washington," dated 1 September 1960.

7. National Marine Consultants, Inc., Santa Barbara, California, "Wave Statistics for Twelve Most Severe Storms Affecting Three selected stations off the coasts of washington and Oregon, During the Period 1950-1960," January 1961; "Oceanographic study for Columbia River Entrance," March 1961; "Wave Statistics for Three Deep Water Stations Along the Oregon-Washingtion Coast," May 1961. 